\section{(1) \\ GEORGE Fox \\ UNIVERSITY}

\section{Digital Commons @ George Fox University}

Western Evangelical Seminary Theses

3-1-1972

\title{
A Pastor's Guidebook for Effective Pastoral Calling
}

Douglas O'Neal Dougherty

\section{Recommended Citation}

Dougherty, Douglas O'Neal, "A Pastor's Guidebook for Effective Pastoral Calling" (1972). Western Evangelical Seminary Theses. 152. https://digitalcommons.georgefox.edu/wes_theses/152

This Paper is brought to you for free and open access by the Western Evangelical Seminary at Digital Commons @ George Fox University. It has been accepted for inclusion in Western Evangelical Seminary Theses by an authorized administrator of Digital Commons @ George Fox University. For more information, please contact arolfe@georgefox.edu. 
A PASTOR'S GUIDEBOOK FOR EFFECTTVE

PASTORAL CALIING

A Graduate Research Project

Presented to

the Faculty of the Graduate School

Western Evangelical Seminary

In Partial Fulfillment

of the Requirements for the Degree

Master of Divinity

by

Douglas O'Neal Dougherty

Merch 1972 
${ }_{7}^{4} 7^{5}$

APPROVED BY

Major Professor:

Cooperative Reader:

27938 
TABLE OF CONPENTS

CHAPTER PAGE

I. INTRODUCTION . . . . . . . . . . . . . . . 1

The Problem ....................... 1

Statement of the problem ................ 1

Importance of the study ................ 1

Limitations of the study .............. 2

Definitions of Terms Used ............... 2

Pastoral calling................. 2

The sick ................... 3

The bereaved .................. 3

The troubled................ 3

The aged .................. 3

Shut-ins.................. 3

Prospective members .............. 3

The routine call............... 3

Organization of the Remainder of the Study ........ 4

Chapter two.................. 4

Chapter three ................. 4

Chapter four................ 5

Chapter five.............. 5

Chapter six ................ 5

Chapter seven ............... 6

Chapter eight .............. 6

Chapter nine ................... 7 
Review of the Iiterature .................7

Review of books used ................ 7

Review of periodicals used ............ 9

II. GENERAL GUIDELINES OF PASTORAL CAIIING .......... 10

Purposes of Pastoral Calling .............. 11

General purposes of pastoral calling ......... 11

Pastor comes to know his people ......... 12

People come to know their pastor.......... 13

Implements preaching with vital homiletical material. 13

Strengthens church finances. . . . . . . . 15

Meets evangelistic opportunities ......... 15

Stimulates church attendance ........... 15

Affords counseling opportunities . . . . . . . 16

Represents Christ and the church ......... 16

Specific purposes of pastoral calling ........ 16

Preparation for Pastoral Calling ........... 17

Personal pastoral preparation .......... 17

Prepare spiritually .............. 17

Prepare mentally . . . . . . . . . 18

Prepare physically ............. 19

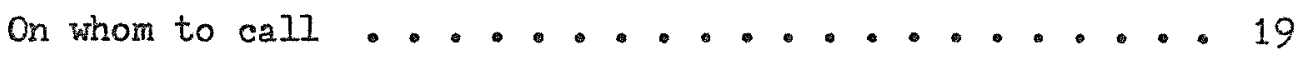

Call according to need .............. 19

Show no partiality ............. 20

Plan calls systamatically ............. 21 


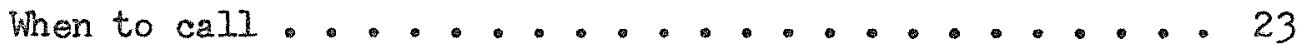

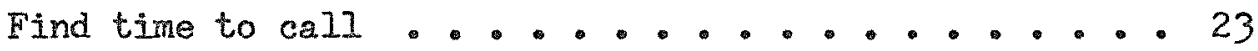

Determine time of day to call ......... 24

Decide whether to call unexpectedly or by appointment . 25

Procodure of Pastoral Calling ... . . . . . . 27

Tntering the home ................ 28

Follow rules of common courtesy ......... 28

Keep calling purpose in mind ........... 29

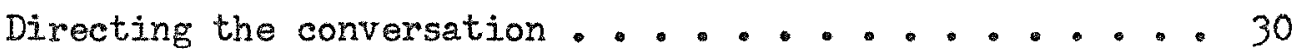

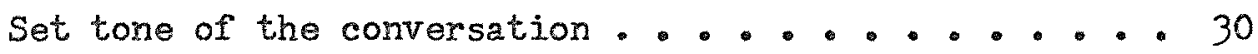

Be a good listener ............... 31

Avoid certain situations ............ 32

Determining the length of the call ........ 33

Terminating the call ............ 34

Possible Results of Pastoral Calling . . . . . . . 35

Pastoral Records for Calling ............ 36

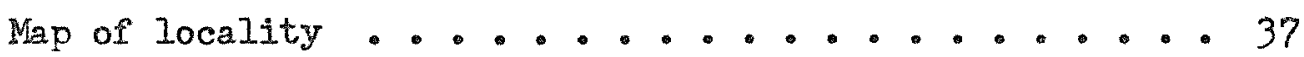

Daily calling ledger ............... 37

Family card file................. 38

Individual card file............. 38

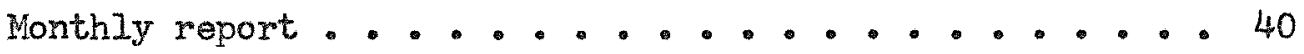

ITI. PASTORAL CALLING ON THE SICK .............. 41

Purposes of Pastoral Calling on the Sick ......... 42

Preparation for Pastoral Calling on the Sick....... 44 
Personal pastoral preparation .......... 44 Prepare spiritually .............. 44 Prepare mentally .............. 45 Prepare physically ............ 45

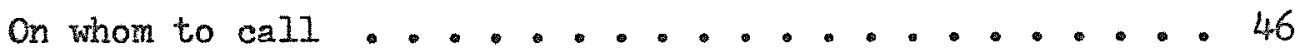
Train parishioners ............. 46 Minister closely to some........... 47

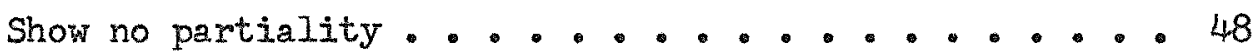

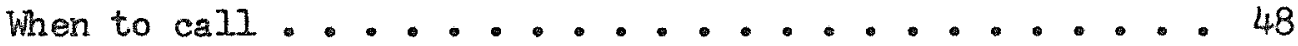
Call promptly .............. 48 Determine calling frequency ......... 49 Be considerate of visiting hours ........ . 49 Procedure of Pastoral Calling on the Sick ....... 50 Entering the sickroom ............. 51 Approach the sickroom ............ 51

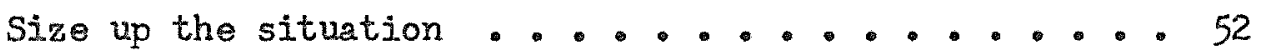
Directing the sickroom call .......... 52 Set tone of the conversation ......... 52 Keep certain facts in mind ........... 56 Terminating the sickroom call ......... 58 Keep call brief. ............. 58 Incorporate Scripture and prayer wisely ... . . . 59 Consider offering communion ........... 61 
vii

CHAPTER

PAGE

Calling on persons needing special consideration .... 61 The pre-surgical case ............ 61

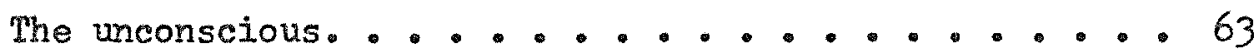

The one with a communicable disease .........63

The dying. .................... 64

The sick or injured child ......... 65

The mentally ill ............. 66

Possible Results of Pastoral Calling on the Sick .... 67

Pastoral Resources for Caliing on the Sick....... 6 ?

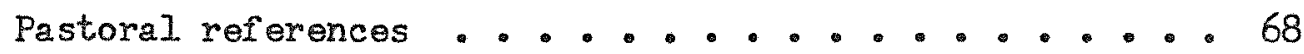

Pamphlets to give to the patient......... 69

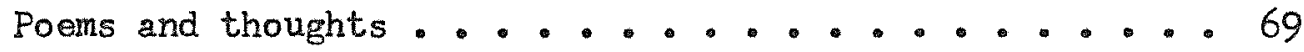

Scripture verses .............. 71

IV. PASTORAL CALIING ON THE BEREAVED ............ 73

Purposes of Pastoral Calling on the Bereaved .......73

Preparation for Pastoral Calling on the Bereaved .....74

Personal pastoral preparation .......... 74

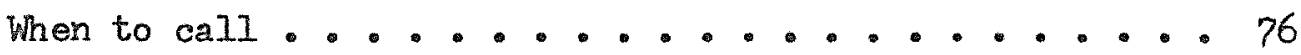

Procedure of Pastoral Calling on the Bereaved ..... 77

Directing the call on the bereaved .......... 77

Be considerate............... 77

Help bereaved through stages of grief ....... 78

Terminating the call on the bereaved ........79

Continuing to call on the bereaved ......... 80 
vili

CHAPTER

PAGE

Possible Results of Pastoral Calling on the Bereaved . . 81

Pastoral Resources for Calling on the Bereaved ...... 82

Pamphlets to give to the bereavod........... 82

Poems and thoughts ............. 82

Scripture verses .................... 84

V. PASTORAL CALLING ON THOSE WTTH SPECIAL NEEDS . . . . . 85

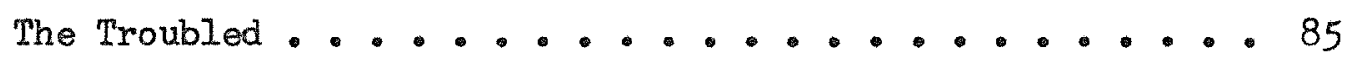

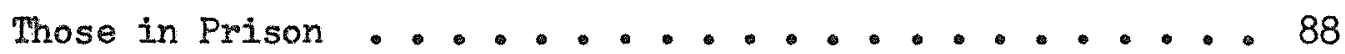

Purposes of pastoral calling on those in prison .... 88

Preparation for pastoral calling on those in prison . . 88

Procedure of pastoral calling on those in prison.... 89

Set tone of the conversation .......... 89

Remember helpful suggestions ............ 91

Continue offering guidance ............ 91

Possible results of pastoral calling on those in prison - 92

Pastoral Resources for Calling on Those with Special Needs - 93

Pamphlets to give to the troubled ......... 93

Poems and thoughts for the troubled .......... 94

Scripture verses ................. 95

VI. PASTORAL CALUING ON THE AGED AND SHUT-INS . . . . . . . 9 ?

Purposes of Pastoral Calling on the Aged and Shut-Ins . . 97

Preparation for Calling on the Aged and Shut-Ins... . 98

Personal pastoral preparation .......... 99

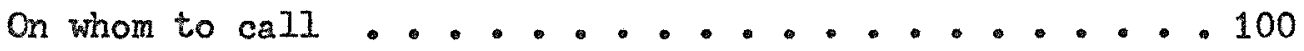

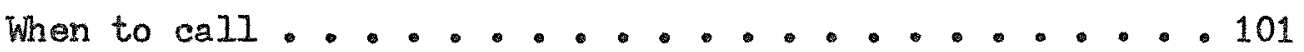


Procedure of Pastoral Calling on the Aged and Shut-Ins - . 101 Directing the call on the aged and shut-ins ...... 101 Set tone of the conversation .................... 101

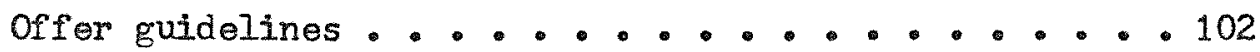

Terminating the call on the aged and shut-ins .... 104 Ignore tine element .............. 104 Employ singing, Scripture, and prayer ........ 104 Consider offering communion .................... 105 Possible Results of Pastoral Calling on the Aged and

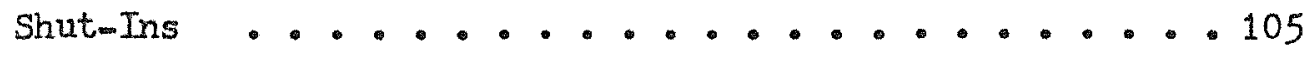
Pastoral Resources for Calling on the Aged and Shut-Ins . 106 Pastoral references .................... 107 Pamphlets to give to the aged and shut-ins....... 107

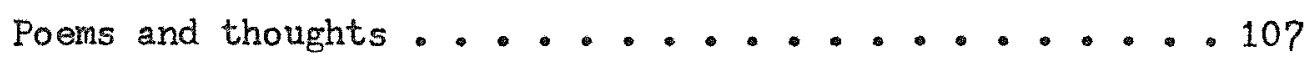
Scripture verses ............... 109 VII. PASTORAL CALITNG ON PROSPECTIVE MEMBERS . . . . . . . 110 Neweomers to the Church .............. 110 Newcomers to the Community ............... 111 The Unevangelized. . . . . . . . . . . . 112 Pastoral Resources for Calling on Prospective Members . . 112 Pamphlets to give to prospective members ........ 113 Scripture verses for the unevangelized ........ 113 VIII. PASTORAL CALIING ON EACH FAMTLY .............. 114 Purposes of Pastoral Calling on Each Family . . . . . 115 
Preparation for Pastoral Calling on Each Family . . . 116 On whom to cal1 ..................... 117

Show no partiality ................ 117

Plan calls systematically ...................

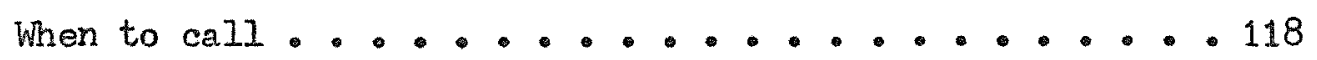
Procedure of Pastoral Calling on Each Family . * . . . 119

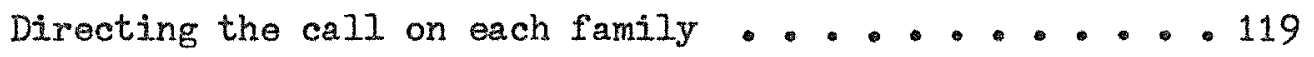

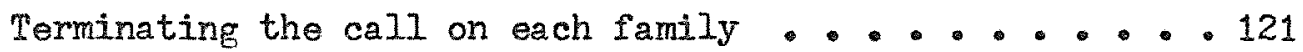
Possible Results of Pastoral Calling on Each Family . . 121 Pastoral Resources for Calling on Each Family . . . . 122 Pamphlets to give to each family . . . . . . . . 122

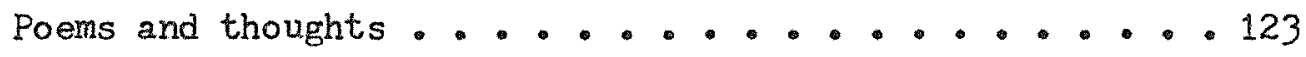
Scxipture verses ..................... 124 IX. SUMMARY AND CONCLUSION . . $\cdot \cdot \cdot \cdot \cdot \cdot \cdot \cdot \cdot \cdot \cdot \cdot \cdot \cdot \cdot \cdot 125$ BIBLIOGRAPHY . . . . . . . . . . . . . . . . . . . . . 134 


\section{CHAPTER I}

\section{INTRODUCTION}

There are many phases of the pastoral ministry, each one having a unique and necessary purpose. A high emphasis has always been placed on the pastor as a preacher. Serving as administrator has also been encouraged. Today, the phase of the pastor as counselor has been reaching the forefront. It is true that these are all vital parts of the pastoral ministry, but there is yet another phase that must not be neglected. This is pastoral calling. Without effectively practicing this phase, the pastor's ministry is lacking and incomplete.

\section{THE PROBLEM}

Statement of the problem. The purpose of this study was (1) to present general guidalines as to the purposes, preparation, procedure, and possible results of pastoral calling; (2) to suggest the contents of a pastoral record system; (3) to present the purposes, preparation, procedure, and possible results of calling on the sick, the bereaved, those with special needs, the aged and shut-ins, prospective members, and each family; (4) to suggest pastoral resources for each type of call; and (5) to present all the material in a way that would be easy to understand and usable for the pastor.

Importance of the study. As stress on the preaching ministry and the newer emphasis of pastoral counseling has increased, some pastors regard pastoral calling as a vanishing tradition and an intolerable task. 
Therefore, this study was an attempt to show, through positive and careful presentation of material, the necessity of this aspect of the pastoral ministry. A second reason this study was important was the necessity of such a guidebook for the pastor. A guidebook was needed for the pastor that contained both a succinct, yot comprehensive, discussion of the various calls the pastor would make and how he would make them; and one that contained suggested pastoral resources to be used when calling.

Limitations of the study. This study was limited in three respects. First, it dealt only with those cases of calling where the pastor went out into the community. This, therefore, eliminated the area of pastoral counseling, where individuals come to the pastor. Secondly, this study was limited to the main types of cases on which the pastor might need to call; however, the general guidelines would offer enough information to enable the pastor to complete any other special cases which may occur. Finally, the research was limited to the use of books and periodicals only.

\section{DEFINITIONS OF TERMS USED}

Pastoral calling. Throughout this study "pastoral calling" was interpreted to mean the personal calls a pastor makes in the homes of a community, in hospitals, and in jails with spiritual ends in view. "Pastoral visitation" and "pastoral calling" were considered synonymous terms in this study. 
The sick. The term "the sick" as employed in this study referred to those suffering from acute illness, which for the most part is of rather limited duration. The term "the sick" also included those who were dying.

The bereaved. In this study "the bereaved" was used to mean those who lost a loved one by death.

The troubled. The term "the troubled" as employed in this study referred to those who are lonely, discouraged, dissatisfied, or have deep spiritual needs.

The aged. In this study "the aged" was used to mean those who are generally restricted to their homes because of advanced age.

Shut-ins. The term "shut-ins" as applied in this study referred to those who are confined to a bed, chair, wheelchair, room, or house because of extended illness or physical disability.

Prospective members. "Prospective members" was used in this study to denote three groups of people-mewcomers to the church, newcomers to the community, and the unevangelized.

The routine call. Throughout this study the term "routine call" was interpreted to mean calling systematically on each church family regardless of their spiritual needs and without specific purpose in the way of church organizational promotion. 
III. ORGANIZATION OF THE REMAINDER OF THE STUDY

General guidelines of pastoral calling were discussed first. The order of the remaining chapters, which discussed particular types of pastoral calls, was according to the urgency of the need.

Chapter two. In the second chapter purposes of pastoral calling. preparation for pastoral calling, procedure of pastoral calling, possible results of pastoral calling, and pastoral records for calling were presented. General and specific purposes were given. Personal pastoral preparation, on whom to call, and when to call were discussed under preparation for pastoral calling. The procedure of pastoral calling was divided into entering the home, directing the conversation, determining the length of the call, and terminating the call. The possible results were stated simply. Finally, pastoral records for calling included discussions concerning the map of locality, daily calling ledger, family card file, individual card file, and monthly report.

Chapter three. In the third chapter the material was presented under purposes, preparation, procedure, particular cases needing special attention, possible results, and pastoral resources for calling on the sick. The purposes of pastoral calling on the sick were stated briefly. The preparation for pastoral calling on the sick was divided into personal pastoral preparation, on whom to call, and when to call. The procedure of pastoral calling on the sick was discussed under entering the sickroom, directing the sickroom call, and terminating the sickroom call. Particular cases needing special consideration included discussions of 
the pre-surgical case, the unconscious, the communicable disease case, the sick or injured child, and the mentally ill. Possible results of pastoral calling on the sick were stated simply. Finally, consideration was given to pastoral resources for calling on the sick.

Chapter four. In chapter four the material concerning pastoral calling on the bereaved was presented under purposes, preparation, procedure, possible results, and pastoral resources for calling on the bereaved. The purposes of pastoral calling on the bereaved were briefly stated. Preparation for pastoral calling on the bereaved included discussions of personal pastoral preparation and when to call. The procedure of pastoral calling on the bereaved was presented under directing the call, terminating the call, and continuing to call on the bereaved. Possible results of pastoral calling on the bereaved were stated simply. Finally, pastoral resources for calling on the bereaved were suggested.

Chapter five. In chapter five material was presented concerning pastoral calling on those: with special needs. Pastoral calling on the troubled was discussed. A discussion of pastoral calling on those in prison was given with respect to purpose, preparation, procedure, and possible results. Finally, suggestions of pastoral resources for calling on those with special needs were presented.

Chapter six. In the sixth chapter material concerning pastoral calling on the aged and shut-ins was presented under purposes, preparation, procedure, possible results, and pastoral resources. Brief 
consideration was given to the purposes of pastoral calling on the aged and shut-ins. Preparation for calling on the aged and shut-ins was discussed under personal pastoral preparation, on whom to call, and when to call. Directing the call and terminating the call were the main areas of discussion concerning the procedure of pastoral calling on the aged and shut-ins. The possible results of pastoral calling on the aged were stated simply. Finally, several suggestions were given concerning pastoral resources for calling on the aged and shut-ins.

Chapter seven. In chapter seven material concerning pastoral calling on prospective members was presented. Consideration was given to pastoral calling on newcomers to the church. A discussion of pastoral calling on newcomers to the community was presented. Pastoral calling on the unevangelized was also discussed. Finally, suggestions of possible pastoral resources for calling on prospective members were made.

Chapter eight. In chapter eight purposes, preparation, procedure, possible results, and pastoral resources were presented concerning pastoral calling on each family of the church. The purposes of pastoral calling on each family were stated briefly. On whom to call and when to call were discussed in preparation for pastoral calling on each family. The procedure of pastoral calling on each family included discussions of directing the call and terminating the call. Possible results of pastoral calling on each family were stated simply. Finally, consideration was given to pastoral resources for calling on each family. 
Chapter nine. In chapter nine the contents of the entire study were summerized and a brief conclusion was given.

\section{REVTEW OF THE LITERATURE}

Review of books used. Much has been written on the total ministry of the pastor; however, few authors dealt extensively with the pastoral calling aspect of the ministry. Eugene Dinsmore Dolloff and Russell I. Dicks were the two authors who contributed the most pertinent and helpful material concerning pastoral calling. Dolloff in his book, The Romance of Doorbells, covered the entire field of pastoral calling. The Romance of Doorbells was found to be a particularly valuable resource in the area of general guidelines, but also contributed excellent material in the specific cases of the sick, and the aged and shut-ins. Russell I. Dicks was of greatest assistance in the areas of the sick, the bereaved, the aged and shut-ins, and the family. His books, How to Make Pastoral Calls and Pastoral Work and Personal Counseling were very helpful. Dicks collaborated with Richard C. Cabot to write one of the finest books ever written concerning pastoral calling on the sick, The Art of Ministering to the Sick.

In the area of general considerations of the pastoral calling ministry, there were several other authorities who deserve special recognition for their work. Nolan B. Harmon wrote his book. Ministerial Ethics and Etiquette, during the $1920^{\circ} \mathrm{s}$; however, the material that he presented was excellent and very much applicable to the pastoral calling ministry today. Lucas Buttry was the author of a very fine book, the 
Calling Program of the Local Church. Buttry was especially helpful in the area of pastoral calling records. The most current book that was of any significant value was The Pastor and His Work written by Homer A. Kent. It was published in 1963. This book by Kent was helpful throughout the study but especially in general guidelines.

In the area of pastoral calling on the sick there were three other authors who made significant contributions to this study. Andrew W. Blackwood wrote his Pastoral Work: A Source Book for Ministers in the middle $1940^{\circ} \mathrm{s}$. This book was found to be of value in the areas of calling on the aged and shut-ins and calling on prospective members, as well as calling on the sick. Another excellent and helpful work was William A. Lauterbach's book, Ministering to the Sick. This book by Lauterbach suggested possible Scripture texts to be used in making various types of sick calls. Important, especially to pastoral calling on the sick who are in the hospital, was The Pastor's Hospital Ministry written by Richard K. Young.

The two most helpful books concerning pastoral calling on the bereaved were Pastoral Work and Personal Counseling by Russell L. Dicks and The Pastor's Hospital Ministry by Richard K. Young.

A recent book by John Caldwell Thiessen, Pastoring the Smaller Church, was of particular value in the area of pastoral calling on those with special needs. Ministering to the Prisoners and Their Families by George C. Kandle and Harry H. Cassler was also an excellent book in this area.

Robert N. Rodenmayer made important contributions in the area of pastoral calling on the prospective members in his book, We Have 
This Ministry.

Although it was written in the $1920^{\circ} \mathrm{s}$, The Pastoral office by James Albert Beebe included some very pertinent material for pastoral calling on the family. In this same area of pastoral calling on the family, Paul Rowntree Clifford made valuable contribution in his book entitled The Pastoral Calling. Pastoral Ministry to Families by John Charles Wynn was also helpful.

Reviow of periodicals used. Some very fine articles on the pastoral calling aspect of the ministry have been written. In the area of general guidelines of pastoral calling James W. Kennedy's "The Doorbell Ministry," Alfred D. Grey's "The Pastoral Ministry," Howard A. Kuhnle's "Pastoral Calling," and W. Curry Mavis" "Must We Surrender Regular Pastoral Calling?" were all very helpful articles.

In the consideration of the various types of calls the following articles proved to be of excellent worth: David E. Sparks' "The Pastor and Hospital Visitation," Richard Hubacek's "Hospital Visitation" and "When Death Comes," Willis A. Reed's "The Pastor and Sick Visitation," William F. Rogers' "The Pastor's Work with Grief," George C. Bonnell's "The Pastor's Role in Counseling the Bereaved," and Harry J. Brevis" "Counseling Prison Inmates." 


\section{CHAPTER II}

\section{GENERAL GUIDELINES OF PASTORAL CAILING}

Pastoral calling is not out of date. As long as the human heart yearns for sympathy and hungers for friendship the pastor may be assured that he is not wasting time when he visits his people....1

The day of pastoral visitation has not passed. Some ministers regard this form of service as a vanishing tradition, and some as an intolerable task, but others find it a priceless privilege. For a man of social instincts and spiritual vision, the hearty welcome offered him in hundreds of homes, not merely because of his personal merit, but as the representative of a great Church and as a messenger of Christ, is one of the most thrilling and inspiring experiences of his life.2

Regular pastoral calling still makes a strong claim for a place in the contemporary pattern of pastoral service. Its real origin with Jesus himself declares its importance. Its history underscores its virility. The contemporary need for it suggests that it is one of the abiding means of the Christian ministry. 3

These quotations well introduce this chapter on the general guidelines of pastoral calling.

In this chapter the material presented is concerned with the general principles and practices of the total program of pastoral calling. The purposes for pastoral calling are set forth. Consideration is given to the pastor's preparation before calling. The procedure of

\footnotetext{
${ }^{1}$ Hampton Adams, The Pastoral Ministry (New York: Cokesbury Press, 1932). p. 58 .

${ }^{2}$ Charles R. Erdman. The Work of the Pastor (Philadelphia: The Westminster Press, 1928), p. 53 .

${ }^{3}$ Curry W. Mavis, "Must We Surrender Regular Pastoral Calling?" Pastoral Psychology, XIV (April, 1963), 49.
} 
the pastoral $c_{a} I l$ is discussed. Possible results from pastoral calling are mentioned. The importance of having pastoral calling records is established with explanation of what to include in a record system.

\section{PURPOSES OF PASTORAI CAILING}

The calling ministry involves much more than just seeing someone for a few minutes and then dismissing them from one's presence and one's mind. Every visit, every contact, is an opportunity to share something, and leave the place and the person spiritually blessed and enriched. 4

In order that this work may be conducted profitably, the first requirement is that every individual visit must be made with some definite purpose. Perfunctory calling, or visits made simply to increase the recorded number of calls, are worse than useless. . . 5

These quotations state well the importance of establishing purposes for pastoral calling prior to actually making visits. Realizing the tremendous value in calling also sends the pastor out with an enthusiasm for the task ahead of him. Both general and specific purposes of pastoral calling are considered.

\section{General Purposes of Pastoral Calling}

Following are eight general purposes for pastoral calling. They indicate well the vital influence pastoral calling done prayerfully and conscientiously can have on the life and growth of a church.

4J. W. Kennedy, "The Doorbell Ministry," Pulpit Digest, XLVI (September, 1965), 16.

$$
5 \text { Erdman, op. cit., p. } 54 .
$$


Pastor comes to know his people. The pastor, to truly be the

"shepherd of his flock," must acquaint himself with his people. He needs to know his people well. Eugene Dolloff in his book, The Romance of Doorbells, pointed out that with few exceptions "the pastor cannot associate names and faces together unless he sees his people in their homes." Knowing the people in their home setting provides the pastor with valuable insight into the lives of his parishioners. Homer A. Kent in his book. The Pastor and His Work, made the comment: ".. Some attitudes which are manifested in the church cannot be understood unless the home conditions are known."?

- A minister cannot love his congregation until he gets to love them as individual men and women and boys and girls. We make pastoral calls in order to get to know our people as individual members of the congregation; to know not only their names, but also their ways of living, their interests, their problems. 8

The minister who places pastoral visitation high on his list comes to know his people well. He becomes acquainted with their needs, their short-comings, their strong points, their fears. He also develops a personal warmth of Iove and understanding, of sympathy and compassion, for them. The pastor who does a great deal of calling will not be tempted to consider his people as statistics but will see them as souls needing reconciliation with Christ and with their fellow men for the sake of christ. One cannot have the touch of Christ without getting close enough to touch people.9

6ugene D. Dolloff. The Romance of Doorbells (Philadelphia: The Judson Press, 1951), p. 28.

7Homer A. Kent. The Pastor and His Work (Chicago: Moody Press, 1963), p. 269.

${ }^{8}$ AJfred D. Grey, "The Pastoral Ministry." Pastoral Psychology. XIV (February, 1963), 22.

9Howard A. Kuhnle, "Pastoral Calling," Christianity Today, IX (June 4, 1965), 11. 
People come to know their pastor. Just as important as the pastor's becoming acquainted with his people is the people's becoming acquainted with their pastor. There needs to be a mutual relationship between pastor and parishioner. The pastor is more likely to receive a sympathetic ear during his sermons when he has established personal rapport with his congregation. An unknown wise person has remarked, "The sermon always sounds better on Sunday when I have had a shake of my minister's hand during the week."10 The pastor must recognize the need of his people to become acquainted with him. Eugene Dolloff made the following comment: ". People want, expect, yearn for, and demand pastoral visitation. Chief among their many reasons for this is their desire to know personally their spiritual shepherd. . .11

The importance of this purpose for pastoral calling is further emphasized by Theodore L. Cuyler in his book, How to Be a Pastor:

After all, the chief power of a Christian minister is heartpower. That is Christ's real power over you and me. The pride of a congregation may be awakened by brilliant pulpit displays; but it is personal attention and affectionate sympathy with each individual that bind our congregations to us with hooks of steel. And when we have grappled the affections of our people to us. they will bear any amount of close, searching truth and of the most pungent rebukes of their personal sins, without flinching. 12

Implements preaching with vital homiletical material. James Albert Beebe stated this purpose well in his book. The Pastoral Orfice:

10 Theodore L. Cuyler, How to Be a Pastor (New York: Baker and Taylor Company, 1890), p. 22; Dolloff, op. cjt. p. 34.

${ }^{11}$ Dolloff, op. eit. p. 35. ${ }^{12}$ Cuyler, op. cit.. p. 23. 
"Pastoral visiting is highly accredited as a method of gathering homiletical materials, of acquiring the truth the congregation may have for the minister."13 Added to Beebe's statement is the following by W. E. Sangster in his Approach to Preaching: ". . Nothing keeps preaching closer to reality than for the preacher to keep close to the people themselves. . ."14

This purpose for pastoral calling is given further acclaim in the following quotations:

Pastoral calling has great value in showing the pastor the needs of the people and thus aiding in effective preaching to his congregation on Sunday. Without pastoral calling, the preacher will often preach above the people's deepest needs. . . 15

- . By some indirect but powerful alchemy the things a minister learns in visiting his people.. become transmuted into sermonic material that can bless and help. Something is always added to a man's preaching when his pastoral visiting is steady and regular, and something vital goes from it when he ceases to visit. . 16

It goes without saying that every sermon must have a specific objective. He who aims at nothing will hit-mothingl Sermonic goals can best be discovered through continuous, devoted parish visitation. 17

13James Albert Beebe, The Pastoral office (New York: The Methodist Book Concern, 1923), p. 276.

14W. E. Sangster. The Approach to Preaching (Philadelphia: The Westminster Press, 1952), p. 80 .

15 Lucas Buttry, The Calling Program of the Local Church (Butler, Indiana: The Higley Press, 1956), p. 17.

16 Nolan B. Harmon, Ministerial Ethics and Etiquette (New York: Abingdon-Cokesbury Press, 1928), p. 92.

17Dolloff, op cit., p. 36. 
Strengthens church finances. Another of the general purposes of pastoral calling is to strengthen the financial position of the church. It must be realized that this is usually not the main purpose for any pastoral call. Lucas Buttry noted that "pastoral calling will aid in the financial support of the church . . It will aid in the giving attitude of his people toward the Lord's work."18 The financial life of the church Is strengthened by church members who are enthusiastic about the work of the Iord. "Unfortunately--yet true it is--people as a rule will support their church financially, and along other lines also, in proportion to the way they like the pastor. ..."19

Meets evangelistic opportunities. Pastoral calling affords the pastor with many golden opportunities for evangelism. It is a certainty that many persons with whom the pastor visits will not know the gospel message. ". God is ever ready to use a devoted minister in a truly marvelous evangelistic way in the quiet of private homes. 'Hand-picked fruit' is generally found to be of superior quality."20

\section{Stimulates church attendance. Another general purpose of} pestoral calling is to stimulate church attendance. The pastor is able to lead his people to deeper commitments to the Lord and to the church by his faithful, loving, and personal interest in them. It is noticeably

$$
\begin{aligned}
& { }^{18} \text { Buttry, op. cit., p. } 19 . \\
& { }^{19} \text { Dolloff, op. cit., pp. } 40-41 .
\end{aligned}
$$


true that a pastor who is faithful in visiting will have church members who are more faithful in their church attendance. 21

\section{Affords counseling opportunities. Through pastoral calling the} pastor often is made aware of problems and situations that, otherwise, he would have never known existed. The pastor who is versed in counseling techniques and knows the distress signals for psychological problems can help his troubled parishioners. He may counsel them himself or refer his cases to other competent counselors or psychiatrists.22

Represents Christ and the church. The final general purpose to be considered is the underlying purpose of all pastoral calling regardless of the individual situations. The minister of the gospel and pastor of the flock must always remember that he is representing his Lord and Master. Jesus Christ. He also represents the church of which he is the spiritual leader.

\section{Specific Purposes of Pastoral Calling}

The specific purposes of pastoral calling are for individual calls and vary with each call. Basically, these purposes are selfexplanatory; however, they are treated further in the ensuing chapters on specific types of pastoral calls.

21 W. B. Riley, Pastoral Problems (New York: Fleming H. Revell Co., 1926), p. 137; Buttry, op. cit.. p. 18; Erdman, op. cit., p. 56.

${ }^{22}$ Paul Rowntree Clifford, The Pastoral Calling (New York; Channel Press, 1961), pp. 79-83. 
1. To comfort and encourage the sick.

2. To console and strengthen the bereaved.

3. To give direction and spiritual guidance to the troubled and to those in prison.

4. To bring cheer and a sense of worth to the aged and shut-ins.

5. To welcome newcomers to the church and community.

6. To share the gospel with the unevangelized.

7. To show an interest in and encourage the church families.

\section{PREPARATION FOR PASTORAL CALLING}

An effective program of pastoral calling does not just happen. A considerable amount of preparation is absolutely necessary. Before embarking on his daily pastoral calls, the pastor must make personal preparation for this personal ministry. The pastor also must know on whom to call and when to call.

Personal Pastoral Preparation

Prepare spiritually. The pastor comes to his people as a representative of Jesus Christ. The pastor, therefore, needs to be closer to the source of his love and spiritual strength than perhaps any other person. The devotional life of the pastor is reflected in his calling ministry.

- Our people are in need of someone who knows, who cares, and who is able to guide toward the Lord Jesus Christ. We will not have all the answers but if we are daily in touch with the One who does, it will be much easier to help the sin-burdened, the confused, the ill, the bereaved, the lonely, and the senior citizens find the answer they need. This is not done by a 'professional man.' but by a pastor who is full of the Holy Spirit, and faith (Acts 6:5), full of love (the I Cor. 13 brand), full of the Word (Psalms 119:11), full of courage (the John the Baptist brand), and full of energy (St. Paul's style).23

23 Paul Wheeler, "Effective Pastoral Calling," The Wesleyan Methodist, CXX (September 1, 1965), 3. 
Prayer is a vital element in the pastor's ministry of visitation. The wise pastor prays before the day's calling program begins to invoke God's blessing and guidance. 24 The following prayer expressed well the needs and concerns the pastor should have as he begins his pastoral calling for the day:

Grant. Lord, I pray, that this day I may be made the messenger of Thy mercy to many. Open in my nature deep springs of love and sympathy and understanding, that when I meet with those who are in deep waters, deep may answer unto deep. Bring me into the divine peace, and let me walk this day in the light of Thy countenance, that all the influences of my person and presence may make for helpfulness. Give me Thy comfort for the sorrowful, Thy cheer for the glad, Thy love for the lonely. Thy riches for the poor, Thy peace for the anxious. May children find me childlike, and the strenuous find me courageous, and the aged find me trustful. So use me, I pray, as to quicken life with the sense of its spiritual complement. where every valley is exalted and every mountain brought low. In Christ. Amen.25

Prepare mentally. It is also important that the pastor be mentally prepared for his pastoral calling. As the pastor contemplates his pastoral calls for the day, he must be alert to the purpose or purposes of each call. The pastor dare not waste his time or the time of his parishioners by mere perfunctory calling. Each call is not just a visit; it is a visit with a purpose. The wise pastor prepares himself mentally before each day's calling. 26

${ }^{24}$ Buttry, op. cit., p. 20 .

25W. H. Griffith Thomes, Ministerial Life and Work (Chicago: The Bible Institute Colportage Assn., 1927), pp. 211-12.

26 Kent, op. sit., p. 268. 
Prepare physically. The pastor must also prepare himself physically for each day's calling program. His physical appearance is important, especially when calling on the sick. For this reason, specific details regarding the pastor"s physical preparation are discussed in chapter three.

On Whom to $\mathrm{CaIl}$

Call according to need. Before the pastor can actually begin his pastoral calling for the day, he must know on whom to call. One must remember that some needs found in the pastor's calling responsibilities naturally take priority over others. W. B. Riley said it this way:

Just as Jesus Christ came "not to call the righteous, but sinners to repentance," so the pastor's first duty should be, not to the healthy, but to the sick; not to the happy, but to the troubled; not to the abundantly blessed, but to the bereft; not to the householder of plenty, but to those of poverty.2?

Russell I. Dicks suggested the following priority calling list:

- . It will not be surprising to those who know my background of hospital work that I place first in pastoral work calling upon the sick and dying. The sick and dying are followed in importance by the bereaved and special cases such as those needing relief, jobs and medical care. . . Next in order of importance for pastoral work are: the shut-ins, new members, prospective members and finally the routine call where no stress is known to be present. . . 28

Edgar N. Jackson wrote an article in the Pastoral Psychology magaine where he suggested that those calls dealing with emotional or spiritual emergencies, such as illness, death, acute personal or family

$27_{\text {Riley, op. cit. p. } 136 .}$

${ }^{28}$ Russell L. Dicks. Pastoral Work and Personal Counseling (New York: The Macmillan Company, 1945) p. 32. 
problems and crises in individual or group life take greatest priority in calling. A second group including the aged, newcomers, newly married, parents of the newly born, and organizational calls that are inevitably a part of church life fall farther on down in the list of calling priorities. 29

Many other writers who dealt with the subject of pastoral calling also suggested lists of calling priority; however, those already given represent them all well. They showed clearly that the pastor must consider, when deciding on whom to call, the "natural" list of calling priorities.

Show no partiality. Another important consideration to be made when planning on whom to call was suggested by Nolan B. Harmon: "The minister is cautioned by all to avoid showing partiality to any special group, elass, or faction among his members, nor should his visiting be confined to any definite group or district."30 There will always be some persons in a congregation who are more enjoyable to visit for one reason or another, but this is when the pastor must remember that he is "shepherd" of the entire flock not just to those with whom he gets along the best. 31 Eugene Dolloff made a statement that makes final clarification on this subject of partiality in pastoral calling:

29 Edgar N. Jackson, "A New Look at Pastoral Calling," Pastoral Psychology, XII (April, 1961), 20. 30 Harmon, loc. cit. 31 Wheeler, loc. cit. 
However, in every parish there will always be those persons who legitimately require more of the pastor's attention than do others. Among those who especially require his help are the shut-ins, the ill, and the dying. To serve these friends in a special manner can never be rightfully construed as favoritism, for they represent every part of the parish-socially, intellectually, geographically, and financially. Adversity refuses to pick and choose. It must also be recognized that a true undershepherd will devote much time and energy in behalf of individuals who find themselves in dire, often tragic, need. No fair-minded person will characterize attention to them as partiality. 32

Plan calls systematically. With the above two considerations in mind, calling in order of greatest need and showing no partiality, it is time to systematically plan the day's calls. This step, as suggested by Lucas Buttry, is one of the most important:

Victory or defeat will often be determined by the plans made for a pastor's calling program. If his plans are haphazard, the program will end in miserable defeat, . . If the pastor's plans are systematically organized, intelligent, comprehensive and yet possible, the pastor will find his program riding through to glorious victory now and for eternity. 33

Based on the current needs brought to the pastor's attention and the amount of scheduled visitation time, the pastor must sit down and make out a list of calls to be made on that particular day. Eugene Dolloff suggested this be done the night before. 34 one must keep in mind that the schedule has to be flexible enough that unexpected changes can be accommodated readily without causing undue upset. As Buttry

32 Eugene Dolloff, The Pastor's Public Relations (Philadelphia: The Judson Press, 1959), $\mathrm{pp}$. 68-69.

33 Buttry, op. cit., p. 23.

${ }^{34}$ Dolloff, The Romance of Doorbells, p. 66 . 
suggested, one cannot be on such a rigid schedule that he becomes a "clock-watcher." A call which was expected to last only fifteen minutes but instead lasts an hour should not cause worry. 35

As to the number of calls to schedule per day, Russell L. Dicks made the following suggestion:

- - Any pastor who regularly has four pastoral contacts a day, as a minimum, who works carefully and honestly, following up those contacts and does the meditation, records, and prayers each calls for, will be a great and an effective pastor. There is no church so small and none so large but that every pastor who serves it should be able to have four pastoral contacts a day. 36

Eugene Dolloff recommended planning at least five or six more routine calls than time will permit as often people are not home. 37 It is difficult to say exactly the number of calls one should plan to make in a given day as it can vary so greatly. The important thing would be to place at the top of one's list all of the emergency calls that must be made and then include the names of several routine calls that could be made if time permitted. As a pastor serves for a time, he could more readily judge the number of calls he could expect to make in a given time depending upon the type of call it is and the total amount of calling time he has.

A good reason for systematically planning on whom to call each day is to assure that a maximum number of calls are made. If a pastor hopes to call routinely in the home of each of his parishioners at least once a

\footnotetext{
35 Buttry, op. cit., p. 26. 36 Dicks, op. cit., pp. 25-26.

37Dolloff, The Romance of Doorbelis, p. 66.
} 
year in addition to keeping up with the emergency calls, he must lay plans carefully. Charles Erdman suggested that by making use of a file which groups all the parishimars according to geographical location one can plan on calling in the homes of those living in the neighborhood where the pastor may need to go that day for an emergency call. 38 There are other methods than the geographic to plan routine calls, such as the seasonal plan, weekly goal plan, time-budgeted plan, or alphabetical plan; 39 but when routine calling must be interspersed with emergency calls, the geographic plan allows for the greatest number of calls to be made.

Therefore, when deciding on whom to call, one must remember to call according to the urgency of the need showing no partiality and being careful to plan out systematically each day the calls to be made.

When to $\mathrm{Ca} 1 \mathrm{I}$

Find time to call. Because the pastoral ministry has so many facets that consume the pastor's time, it is necessary for the pastor to carefully schedule his work. Too often the pastoral calling portion of one's ministry is pushed aside by sermon preparation, comittee meetings, counseling, and other office responsibilities.

- - Seldom does a minister say. "I simply cannot find time to prepare my sermons." Sermon preparation is rightfully considered obligatory. Happy is the pastor who takes a similar attitude with respect to the equally imperative ministry of visitation. 40

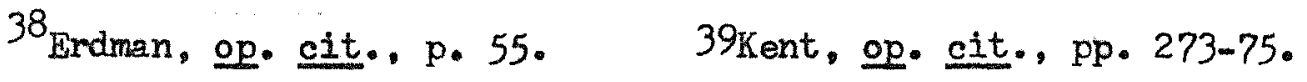

${ }^{40}$ Dolloff, The Romance of Doorbells, p. 53. 
If pastoral calling is going to be a vital reality in one's ministry, then one must evaluate his total ministry to make sure that pastoral calling takes precedence over lesser tasks. Curry W. Mavis in an article entitled, "Must We Surrender Regular Pastoral Calling?" suggested that the pastor who does not seem to have time for an adequate calling program may, in some cases, revise his own schedule to give regular pastoral calling a higher priority over lesser tasks. 41

Eugene Dolloff related in his book, The Romance of Doorbells. that there are certain non-essentials in most pastor's ministry that can be eliminated. These non-essentials center in the area of the pastor's being "the glorified chore boy" of the parish. 42 Dolloff further stated that the pastor must discipline himself with respect to time. He must discern the wisdom of limiting his activities to those areas which contribute the most to an effective ministry. Also, he must do his utmost to remember that time lost is gone forever. 43

Determine time of day to call. Important to the pastor's calling program is having a set time of day in which to do his calling. Both the pastor and the congregation may be more at ease when they know that at certain specified times the pastor will be making his daily pastoral calls. What time of day should this be? John C. Thiessen, author of Pastoring the Smaller Church, suggested that pastors today return to the

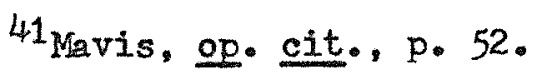

42 Dolloff, The Romance of Doorbells, p. 56. 43 Tbid.. pp. 58-62. 
custom of studying in the morning and calling in the afternoons, except on Saturdays and Sundays. This gives the woman time to get her daily housework done in the morning and also brings the pastor to the home when children will be coming home from school. Therefore, he can get to know the children in the family also which is very important. 44 In order to see the father of the house, Charles Erdman suggested a brief call to his place of business and employment could prove very effective if one was careful not to intrude or interrupt necessary tasks. 45 The pastor needs to get a good start and, therefore, should be out doing his calling by two $0^{\circ}$ clock. 46 It is important, however, to keep in mind that the pastor dare not rely completely on afternoon calling. Emergeney cases must be called upon as soon as possible without regard to time of day. Also, as Lucas Buttry remarked, some calls will have to be made in the evening when the husband is home. 47

Decide whether to call unexpectedly or by appointment. There does not seem to be universal agreement on the matter of calling unexpectedly or by appointment. Some, such as Theodore Cuyler, favored the unexpected visit:

I have seldom found it wise to send word in advance to families in my parish that I would visit them on a certain day or hour. For

44 John CaIdwell Thiessen. Pastoring the Smaller Church (Grand Rapids: Zondervan Publishing House, 1962). pp. 95-96.

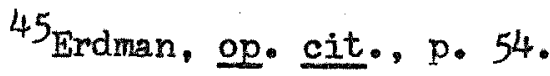

${ }^{46}$ Dolloff. The Romance of Doorbells, p. 67.

47Buttry, op. cit., p. 22 . 
I might be prevented from coming, and thus subject them to disappointment and annoyance. . - If you come in upon your people unawares, - . It depends very much upon yourself whether you are cordially welcomed. If you enter the house with a hearty salutation and a kind word . . . and if you tell them "to allow you to sit down among them as they are,".. you will soon be perfectly at home with them. 48

Lucas Buttry in his book, The Calling Program of the Local Church, was in agreement with Cuyler. 49

Others, however, definitely favored calling by appointment as they felt too much time is wasted when people are not at home. The Rev. A.J. Davidson made this statement:

This pastor [Rev. A. J. Davidson] was beginning to believe that pastoral calling was obsolete after he had made many pastoral calls and so many times found no one home or not prepared. He changed to calling by appointment and found this very successful. 50

Russell L. Dicks also suggested calling by appointment because it makes routine calling too difficult if the pastor is constantly hindered by not finding people at home or finding them unprepared. 51

Therefore, as the pastor becomes acquainted with his parishioners, he must decide which is the wisest, calling unexpectedly or by appointment. This decision might vary from person to person. If one is calling geographically, Lloyd Perry and Edward Lias in their Manual of Pastoral Problems and Procedures, suggested that an announcement in the bulletin

$$
\begin{aligned}
& { }^{48} \text { Cuyler, op. cit., p. 31. } 49 \text { Buttry, op. cit. p. } 26 . \\
& 50 \mathrm{~J} . \text { A. Davidson, "Is Pastoral Calling Obsolete?" Pastoral }
\end{aligned}
$$
Psychology, XV (March, 1964), 46.

${ }^{51}$ Russell L. Dicks, How to Make Pastoral Calls (St. Louis, Missouri: The Bethany Press. 1962), p. 15. 
and from the pulpit the streets where calling would proceed in the following week would be helpful.52 This idea might serve as a compromise between calling completely unexpectedly and setting up an appointment by telephone or mail. Let each pastor carefully consider this matter and decide wisely, through experience, what is best for his particular congregation.

In determining when to make pastoral calls, therefore, one must first make the time to call, then decide the best time of day to call for the greatest success, and finally come to a decision whether to call unexpectedly or by appointment.

\section{PROCEDURE OF PASTORAL CALLING}

Because each pastor has his own unique personality and ways of doing things, no standard procedure of calling could be stated that would be universally workable for all. Andrew Blackwood stated it this way:

- - if you ask an effective pastor how to make a call, he can scarcely tell. The answers vary according to the personality of the minister, the prevailing climate of the home, the season of the year, and other factors hard to define. Whatever the reason, scarcely any two calls prove to be the same. . . . 53

However, there are certain basic procedural guidelines that are applicable to all pastors regardless of their individual personalities. Four main areas are discussed in this section: entering the home,

52 Lloyd Merle Perry and Edward John Lias, A Manual of Pastoral Problems and Procedures (Grand Rapids: Baker Book House, 1964), p. 144.

53 Andrew W. Blackwood, Pastoral Work: A Source Book for Ministers (Philadelphia: The Westminster Press, 1945), p. 61. 
directing the conversation, determining the length of the call, and terminating the call.

\section{Entering the Home}

Follow rules of common courtesy. Under most circumstances the pastor should do his pastoral calling alone. People want the pastor and no one else and will not discuss their vital problems with a third party present. 54 It is also important that the pastor be tactfully courteous at all times. As he reaches the place where he is to call, he should approach in the spirit of prayer. If calling at a home, knock and ring persistently.55 If no one answers, the pastor should leave his calling card 56 or do as Charles Erdman suggested:

- - When the person on whom the pastor has tried to call is not found at home, a little note, written the same evening, expressing regret and stating the purpose of the call, is deeply appreciated and makes an abiding impression. 57

When the door is opened, be pleasant and enthusiastic. 58 "If there is no invitation to enter, make the best of the door conversation." 59 Courtesy leads the pastor to suggest calling again if he has come at an inconvenient time.60 Additional common courtesies were suggested by

${ }^{54}$ Dolloff. The Romance of Doorbells, p. 72 .

55 Perry and Lias, op. cit., p. 145. 56 Kent, op. cit., p. 272.

57Erdman, op. cit., p. 55 .

${ }^{58}$ Dolloff, The Romance of Doorbel1s, p. 78 .

59 Perry and Lias, 10e. eit.

60 Henry Edwin Savage, Pastoral Visitation (New York: Iongmans, Green and Co.. 1903), p. 45; Buttry, op. cit. p. 20. 
Andrew W. Blackwood:

Outwardly, at least the minister acts as if he were making a social call. However, if he finds people at home, he does not leave a card. Unless the weather is cold or inclement, he removes his hat before anyone opens the door. If he is wearing overshoes he removes them, as well as the topcoat. The rubbers he leaves outside; the umbrella he puts where the hostess indicates. So he does with hat and overcoat. Not every person he visits will expect such courtesies, but still he ought to keep in practice. In short, let him act like a gentleman. 61

Keep calling purpose in mind. The following two quotations stated

well the importance for the pastor of keeping the calling purpose upperm

most in his mind as he enters the home:

The pastor should seek to fulfill the purpose of each call. What this purpose is should be determined before the eall is made. Unless he is definitely guided by the Spirit to depart from this purpose, he should pursue it. Also, as he goes, he should be prepared by prayer and a heart full of pertinent scripture to use in fulfilling the purpose of the call. 62

The wise pastor will prayerfully approach each eall with the purpose in mind of helping spiritually each person upon whom he calls. He will forget himself and his problems, and seek to view them and their problems. This will call for a real love of the shepherd for his sheep, and will pay off divine dividends in his pastoral work. 63

Consideration should also be made as to whether a call should be one of a professional or a social nature:". . the circumstances of each case must determine the exact nature of the ca11."64 Nolan B. Harmon suggested that a certain amount of light conversation is expected of the pastor as of any other person; but the call should be of spiritual

$$
\begin{aligned}
& 61_{\text {Blackwood, op. cit., p. 62. }} 62_{\text {Kent, op. cit., p. } 271 .} \\
& 63_{\text {Buttry, op. cit., p. 30. }} 64 \text { Erdman, op. cit. pp. 54-55. }
\end{aligned}
$$


value and not merely to cultivate friendly relations.65 Alfred D. Grey stated this idea well:

As to calling procedure, the minister is not making a social call. He is going to the home as a pastor. He is under the guidance of the Holy Spirit who is directing him to tend and to feed the flock of God . He comes as a messenger of God's grace. He is not his own. . . 66

\section{Directing the Conversation}

Set tone of the conversation. ". . The first and essential factor in a minister's approach, if he is to achieve anything whatever, is a genuine interest in the people whom he goes to see; without that all is lost from the onset. . ."67 The pastor needs to cultivate the ability to converse cordially when he meets people. If the pastor can feel at ease and converse naturally, he will make the poople whom he visits also feel at ease.68 It must also be kept in mind that the degree to which the pastor dominates the conversation is determined by the type of person or persons on whom he is calling and the circumstances of the call. The pastor will be obliged to do most of the talking when visiting introverts. 69

The tone of the conversation is first one of informality, beginning with the present situation of the home and family activities. The pastor may then gradually begin discussing general church activities

$$
\begin{aligned}
& \text { 65 Harmon, op. cit., p. 94. } 66_{\mathrm{Grey}} \text { op. cit., p. } 23 . \\
& \text { 67Clifford, op. cit., p. 93. 68 Thiessen, op. cit.. p. } 96 . \\
& { }^{69} \text { Blackwood, op. cit., p. } 63 .
\end{aligned}
$$


and, finally, personal Christian living.70 The important thing in deciding what to say was well stated by J. H. Jowett:

- . Our God will inspire the counsel if we will cherish and seek His glory. He will appoint the means if we will revere His ends. - . We neod not trouble about the details of our approach to the individual if only our controlling purpose is clean and lorty. 71

Religious conversation should never be forced as this is ". . most repugnant to all the finest instincts of a true man. He simplin cannot do it. For that is to debase what is noblest and holiest and best into a mere professional jargon..." 72

Be a good listener. A very important qualification of the pastoral visitor is that he be a good listener. J.H. Jowett suggested that sympathetic listening is actually a ministry in itself. ". . You will find that sometimes this is a.ll that a man requires, a sympathetic audience. It is not that he needs your speech: he needs your ears. . . "73 The pastor who is a good listener will not hear mere words but will be able to interpret the meaning of what is said detecting the emotional overtones and feelings of the one whom he is visiting. 74

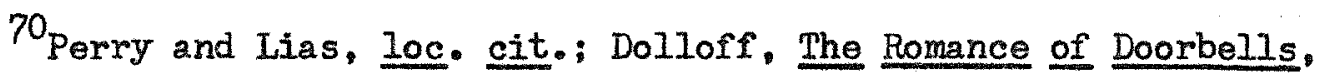
p. 82 。

$71 \mathrm{~J} . \mathrm{H}$. Jowett, The Preacher His Life and Work (New York: George H. Doran Company, 1912), p. 192 .

$$
\begin{aligned}
& 72 \text { Savage, op. cit., p. 38. } 73 \text { Jowett, op. cit. p. } 188 . \\
& 74 \mathrm{clifford,} \mathrm{op.} \mathrm{cit.} \mathrm{p.} \mathrm{p.} 94 .
\end{aligned}
$$
}


Avoid certain situations. The pastor does not have the time to waste in idle chatter. When calling on his parishioners, the pastor should frown down all attempts at gossip. He ought never to speak disparagingly of others. His ears should be sealed against malicious scandal concerning his parishioners or anyone else. A mistake by the pastor in this area of gossip may have far-reaching results. His ministry may be severely crippled by any mistake here. 75

The reputation of the pastor is very important to his effective ministry. He needs to be careful to guard his own essential character as pastor and ambassador of Jesus Christ. It is necessary then that the pastor avoid undue familiarity with women. He must be very careful in his calling on women alone which could give rise to talk. Walter E. Schuette suggested that in questionable situations the pastor may take his wife along or even a small child.76 When a pastor comes to be well known in the community, he need not be so vigilantly on guard against slander to his reputation as when he is a newcomer; however, any imprudence should always be avoided. 77

There are several other areas in which the pastor must be careful as he directs the course of the conversation. He must "never repeat

${ }^{75}$ Cuyler, op. cit. p. 32; Thiessen, loc. cit.

76 WaIter E. Schuette, The Minister's Personal Guide (New York: Harper and Brothers Publishers, 1953), p. 52 .

77Harmon, op. cit., p. 102. 
anything to anybody which is given in confidence, expressed or implied."78 Also the pastor needs to guard against talking too much about himself remembering that his work is to help and not to brag about the pastor.79 Finally, as an ambassador of Christ, the pastor must at all times be tactful and above reproach in telling jokes. 80

Determining the Length of the Call

It is impossible to state the exact amount of time the pastor should allot for each call. The length of a call will depend upon its nature. ". - Conditions may require a call to continue three or four times as long as its immediate predecessor. . . 1181

"The call need not be long, but it should be long enough to fulfill the purpose at hand. - "82 The average call need not consume more than fifteen to twenty minutes or approximately three calls per hour. 83 The pastor must be careful, however, not to be so concerned about keeping the call brief that he becomes a "clock-watcher." On the other hand, he dare not yield to the temptation of prolonging a call because of

${ }^{78}$ Dolloff. The Romance of Doorbells, p. 85.

${ }^{79}$ Buttry, op. cit., p. 29.

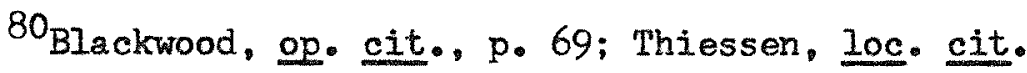

${ }^{81}$ Dolloff, The Romance of Doorbells. p. 68.

82 Kent, op. cit., p. 271.

${ }^{83}$ Dolloff, The Romance of Doorbells, p. 69. 
particularly kind hospitality. This is one of the quickest ways to ruin a calling program. 84

Terminating the Cal1

As Homer A. Kent suggested, usually each call should conclude with the reading of a short portion of Scripture and a word of prayer. 85 This should be done as a natural outcome of the conversation, however, not as an expected duty. Some authors, such as Eugene Dolloff, advocated a brief prayer in connection with about half the calls but seldom reading of Scripture. This feeling is exclusive of visits made on the sick and shut-ins where prayer is almost universally offered. 86 A dependency on the Spirit of God and a positive attitude as suggested by Nolan $B$. Harmon should be the guideline in how to terminate a call.

It would seem, therefore, that the minister should enter a home with the idea that he will have a brief, helpful prayer before he leaves unless conditions make praying inappropriate, rather than with the negative attitude that he may perhaps have prayer if conditions demand it. 87

Once you have brought the call to a close in the most appropriate manner for the particular situation and state that you must go, make it an ironclad rule to do just that. 88

${ }^{84}$ Ibid. $\quad 85$ Kent, op. cit. p. 272.

${ }^{86}$ Dolloff. The Romance of Doorbe11s, pp. $88 \mathrm{~m} 89$.

87 Harmon, op. cit., p. 96.

${ }^{88}$ Dolloff. The Romance of Doorbells. p. 90 . 
Andrew W. Blackwood summarized well the procedure one should

follow in making a pastoral call:

In short, enter the home as a friend. Tarry ten or fifteen minutes. Keep the windows of the soul wide open to sense what is needed most. Serve these friends as their spiritual physician. When you leave, do so as the pastor of the ontire family, including the absent ones. .. 89

\section{POSSIBLE RESULTS OF PASTORAL CALIING}

It is impossible to predict or state just exactly what the result of a pastoral call is going to be. However, there are certain results that one might expect from the pastoral calling program. To a great extent the results are simply the purposes being actualized. However, the results are not always what the purposes suggest they should be. Andrew W. Blackwood stated this idea well:

Do not feel disheartened if a call appears fruitless. Even the noblest saint cannot dwell continually on the mountaintop. If a family seems below par spiritually, the pastor's coming ought to prove timely. - $90^{\circ}$ No one can tell which calls have done good, or, it may be, harm. $90^{\circ}$

Homer A. Kent suggested several possible results of pastoral visitation. It enriches the pastor's own life. It keeps his ministry down to earth, giving him illustrations from life. The pastor is able to preach and pray more sympathetically when he has been out calling. It increases church attendance. The pastor gains the confidence of his parishioners. Finally, Kent suggested that pastoral visitation provides

${ }^{89}$ Blackwood, op. it., pp. $66-67$.

${ }^{90}$ Ibid.. p. 69. 
an opportunity for imparting spiritual truth in a direct and effective way. 91

There is one other possible result that bears mention. In this day when pastoral counseling has been greatly emphasized, Alfred D. Grey in his article, "The Pastoral Ministry," indicated that pastoral calling may result in pastoral counseling. He made the point that "pastoral calling is fundamental in the matter of pastoral counseling. For only as the minister knows the people is he able to deal with their personal concerns. . ".92

\section{PASTORAL RECORDS FOR CALLING}

To be efficient, a pastor will be required to have adequate records of his calling program, and to keep such records up to date. - - Records will take important time from the pastor or his secretary, but the few minutes involved each day in recording the data gained will more than repay the pastor in a span of time for keeping a good record system. .. $.93^{2}$

Lucas Buttry expressed well the importance of a good record system for an effective pastoral calling program. Records are indispensable to the pastoral calling program for no pastor could possibly remember the important data concerning all his parishioners, not to mention the ever-changing lists of those who are ill and others needing special attention.

\footnotetext{
91 Kent, op. cit., pp. $275-76$. 
The matter of calling records are considered under the following sections: map of locality, daily calling ledger, family card file, individual card file, and monthly report.

\section{Map of Locality}

A valuable aid to the pastor's calling program is a large map on his study wall. On this map the pastor has the location of all his parishioners' homes marked. He may use colored pins as symbols denoting the type of call to be made on each home. The value of having a map of this kind is to show the pastor the geographical location and proximity of the members, thus aiding him in quickly noting on whom to call when he has to go to a particular geographical area.94

\section{Daily Calling Ledger}

The daily calling ledger is a notebook used by the pastor for each day's calling. The pastor lists the names and addresses of those on whom he plans to call that day before he begins his calling. After making a call the pastor records any pertinent information that should be remembered. Upon returning to the office he may transfer the information onto the individual's card. The pastor must be careful not to write information during the actual call or while still in the view of the person on whom he is calling. The ledger also keeps an accurate record as to the number of calls made. It is invaluable for writing up a monthly calling report.95

$$
94 \text { Ibid. p. } 31 . \quad 95 \text { Ibid., p. } 35 .
$$




\section{Family Card File}

The names of each family of the entire community in any way connected with the Sunday School or church is placed on a separate card. On this card appears the full name of the husband; under his name should be the name of his wife and each of his children. Pertinent information about the family can be recorded on the bottom of the card. The back of the card may be used by the pastor to record his calls made on that family. By recording his calls in this manner, the pastor is able to readily find when he last called on a particular family. These cards should be filed in alphabetical order by the last name of each family.96

\section{Individual Card File}

The name of each individual connected in any way with the church should be placed on a separate card in a special "classified" file. The front of the card should have the person's name, his status in the church, his birthday, his address and telephone number, and general information (such as schooling, employment, hobbies, talents, offices held in church, relation to other members, and other outstanding facts). The back of the card can be used for pastoral record of visits to the individual and spiritual direction given. The information recorded by the pastor should include the date, type of call, remarks as to the effects of the call, and any other pertinent information helpful in future dealings with the individual. This individual card file should be considered highly

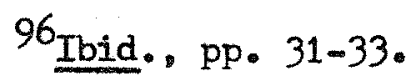


confidential and used by the pastor only. This also is an alphabetized file. 97

The individual card file may be indexed in a different way for the pastor's calling program. Gaines S. Dobbins has suggested that the "calling file" be indexed according to need as follows:

(1) Energency cases--those who need immediate attention because of accident or acute illness or bereavement or unusual distress. (2) Chronic cases-invalids, incurables, the aged, shut-ins, the troubled of long standing. (3) Prospective members-children looking toward reception into the church, unreached outsiders to be evangelized. unaffiliated and straying church members to be reclaimed, newcomers to be welcomed and invited. (4) The in-service group-comrades in the service of the church, deacons and their wives, general officers, officers and teachers of the Sunday school. leaders of the several church organizations, helpers in the worship services, chairmen of committees, and the like. (5) Prospective service group--persons with leadership potential who should be interested, instructed, enlisted. (6) Problem persons--the mentally defective, the maladjusted, the defeated, the eccentric, the perverted, the neurotic. (7) The unacquainted--church members and others who are strangers, whom the pastor can come to know through a personal visit. 98

One would not have to divide his file into quite as many sections as did Dobbins. Each pastor must decide for himself how he wants to keep his records. If the pastor finds the foregoing record system causing too much "book work," he should modify it to meet his own needs. The important thing to remember is that one should always keep up to date whatever record he has. 99

97 Ibid. $\mathrm{p} .33$.

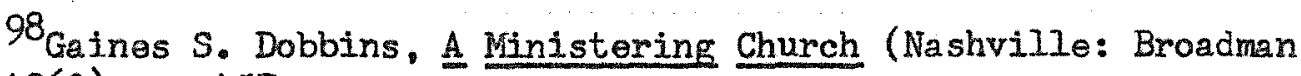
Press, 1960), p. 157.

99 Buttry, op. cit., p. 30 . 
Monthly Report

Many churches ask their pastors to provide a monthly summary of the activities that he has accomplished during the month. Included in this report is a statement or two concerning what he has done in the way of pastoral calling. This report is presented to the deacons (or trustees) at their monthly meeting. The report is valuable to both the deacons and the pastor himself. The deacons gain valuable insight into the program being carried on by the pastor; the pastor is given extra incentive to do this important work because he knows that he will have to report. 100 
CHAPTER III

\section{PASTORAL CALIING ON THE SICK}

What a tremendous opportunity and yet a great responsibility is the pastoral calling program on the sick. Visitation of the sick is one of the most urgent tasks of the ministry and dare not be neglected. It is also a precious privilege. ". Here is the pastor's golden opportunity to point the soul to God, the One who is sufficient for every circumstance."1 Almost always, calling upon the sick takes precedence over all other types of calling and certainly deserves immediate attention. Eugene Dolloff worded well a statement that demonstrates just how important this type of calling really is:

Calling upon the sick is an imperative. Other plans must be sidetracked, other functions must be fitted into the pastor's program at a later hour or day, that these vitally important visits may be made immediately. To be sure, the minister must plan his work and do his best to work his plan, but over and always his schedule must be sufficiently elastic to admit of sudden and drastic change whenever the need arises.2

In considering pastoral calling on the sick, the material is presented in five areas: purposes of pastoral calling on the sick, preparation for pastoral calling on the sick, procedure of pastoral calling on the sick, possible results of pastoral calling on the sick,

${ }^{1}$ Homer A. Kent, Sr.. The Pastor and His Work (Chicago: Moody Press, 1963), p. 278.

2Eugene D. Dolloff, The Romance of Doorbells (Philadelphia: The Judson Press, 1951), p. 94. 
and pastoral resources for calling on the sick.

\section{PURPOSES OF PASTORAI CAILING ON THE SICK}

Russell I. Dicks, a leading authority in the area of visitation of the sick, related that one of the chief characteristics of illness is a sense of isolation which causes the patient to feel in some cases that even God has deserted him. The pastor's presence, much more than his words, helps the sick one to realize the presence of God with him in time of illness. 3 The pastor, who is filled with the love of God, desires to go to the sick in their affliction. Willis A. Reed stated it well in his article, "The Pastor and Sick Visitation":

- The pastor as a shepherd to his people is constrained out of love for all men to visit and share the burdens of the sick. The love of Christ becomes the motivation to go and comfort them with the assurance that the Iord has not promised to keep us from suffering, but to sustain us in the midst of it. 4

James A. Beebe has suggested that "the pastor should have two ends in view in visiting the sick: (1) composing the spirit of the patient, and (2) being a good friend to the family." 5 The pastor, then, is not just to comfort and strengthen the spirit of the patient but also to minister to the needs of his family. The family is often very

${ }^{3}$ Russell I. Dicks, How to Make Pastoral Calls (St. Iouis, Missouri: The Bethany Press, 1962), p. 9.

"Willis A. Reed, "The Pastor and Sick Visitation," Christianity Today, VI (June 8, 1962), 6 .

5 James Albert Beebe, The Pastoral Office (New York: The Methodist Book Concern, 1923), p. 284. 
sensitive during theiliness of a loved one. Walter E. Schuette made the following comment on this point:

I take for granted that the understanding minister will realize that, in the case of serious illness, he has an important service to render, not only to the sick but to the family of the sick. IIIness is often used in God's providence to open doors, break down resistances and rout indifference in hearts and souls which He has been unable to reach by other means. It is for God's servant to consider this, and wisely to make use of the offered opportunities. But let it be borne in mind that wisdom must dominate. . . 6

Eugene D. Dolloff suggested that there are three major objectives or purposes which should motivate the pastor in calling on the sick: (1) to express sincere sympathy, (2) to advise in the realm of the spiritual, (3) to exercise a ministry of physical healing.7 The first two of these purposes may be incorporated into the already mentioned purpose of comforting and strengthening the sick. However, this third purpose is new; it points out the importance of the pastor being a man of prayer and faith. Who else would be expected to invoke God's power to hear the sick, but the pastor?

In addition to comforting and strengthening the sick, being a good friend to the patient's family, and exercising the ministry of physical healing, one final purpose needs to be mentioned. The pastoral call to the sick can aid in ". . the growth of the soul at a time

6 Walter E. Schuette, The Minister's Personal Guide (New York: Harper and Brothers Publishers, 1953), p. 50 .

7Dolloff, op. cit., p. 100. 
when pain, sorrow, frustration, and surprise bring experiences that invite a new start in life..." 8

II. PREPARATION FOR PASTORAL CALLING ON THE SICK

In making pastoral calls on the sick, one must consider three areas of preparation: personal pastoral preparation, on whom to call, and when to call.

Personal Pastoral Preparation

Prepare spiritually. ". - No man can give another that which he himself does not possess.. ." of foremost importance to the pastor who plans to call on the sick is the necessity of he himself being spiritually prepared for such an important task. The pastor's own heart must be filled with faith and love which comes only from his Iord and Savior, Jesus Christ. In discussing preparation for sick visitation, Homer A. Kent stated: "Surely the pastor ought to prepare his own heart by asking the Lord for guidance and help as he ministers to the sick. He ought to consider the spiritual need of the one upon whom he is to call. . .110 The supreme importance of the pastor's being spiritually prepared is well stated in this sentence: ". . Only

${ }^{8}$ Richard C. Cabot and Russell L. Dicks, The Art of Ministering to the Sick (New York: The Macmillan Company, 1942), p. 19 .

9Dolloff, op. cit., p. 117.

10 Kent, op. cit., p. 280. 
a man of faith in God can arouse and develop faith in another. . ."11

Prepare mentally. The pastor must be mentally prepared before undertaking this tremendous ministry of calling on the sick. This ministry is not as easy as some may think it to be. This truth was made quite evident in the following comment by Walter E. Schuette:

Contrary to some people's ideas, calling on the sick is one of the minister's most difficult and perplexing responsibilities. This is all the more disquieting because there is nothing more important on the pastor's schedule than his ministry to the sick. . 12

The pastor needs to have a practical knowledge of human nature and wisdom to apply the Word of God.13 Before calling on the sick he should find out all he can about the nature of the illness. He should be aware of the policies of the hospital or sickroom of the patient whom he is to visit. Andrew W. Blackwood suggested that the pastor be mentally and spiritually alert when he visits the sick because"... when he enters a sick chamber he cannot be sure what to expect. . .14

Prepare physically. One must not overlook the importance of the pastor's making adequate physical preparation for his calling on the sick. There are certain physical preparations which the pastor should

${ }^{11}$ Dolloff, loc. cit. $\quad 12$ Schuette, op. cit., p. 46.

13William A. Lauterbach, Ministering to the Sick (St. Louis, Missouri: Concordia Publishing House, 1955), p. 7 .

14Andrew W. Blackwood, Pastoral Work: A Source Book for Ministers (Philadelphia: The Westminster Press, 1945), p. 102. 
regularly practice. First of all, it is important to realize that many sick people are hyper-sensitive to odors. Therefore, the pastor ought to be very careful to avoid carrying into the sickroom such pungent odors as those associated with tobacco, liquor, hair tonic, face lotions, moth balls, cleaning fluid, gasoline, and even particularly potent mouth washes. A patient may have a hard time concentrating on what the pastor says when he is bothered by an odor from the pastor. 15 Another area of physical preparation that the pastor must consider as he visits the sick is his personal appearance--namely, his clothes. If the pastor dresses so that no one item of apparel or combination of items attracts attention, he is probably well dressed for visiting the sick. Unusual and bizarre items of clothing or a sturning ensemble of gaudy dress is distracting to patients and focuses attention upon the pastor rather than the patient. Because of heightened sensitivities of sick people, the pastor should be consistently careful and considerate about his physical appearance. 16

\section{On Whom to $\mathrm{Ca} 11$}

Train parishioners. Parishioners must be trained to notify the pastor when illness occurs. Often people become offended and doubt the pastor's efficiency if he fails to know about any case of iliness.

15James H. Burns, "The Sick," Pastoral Care (New York: AbingdonCokesbury Press, 1951), p. 154 .

${ }^{16}$ Ibid.. p. 155; Blackwood, op. cit., p. 112. 
- - True, sometimes he does not know about a member's illness for several days. The people in the home call the doctor to come and minister to the sick; they expect him to come, and he does. They do not call the pastor, but they expect him to come just the same. They go on the assumption that he will find out in some way. Often they are highly offended if he does not find it out and does not call. Efforts should be made to instruct the church along this line. The pastor is there to minister, but he cannot minister unless he knows the need.17

There are several dependable agents, as suggested by Eugene Dolloff, that the pastor can employ to furnish him with the needed information. First, he can have the church school teachers inform him of absences due to illness. Second, the pastor can print a note in the bulletin requesting that he be notified of ill persons. Third, information cards in the pews could have a space for indicating one who is sick. Hospitals are glad to cooperate, particulary if they have a chaplain who makes regular visitation calls. Finally, the newspaper. radio news, and informal conversation might also alert the pastor to ones who need a call due to illness. 18

Minister closely to some. Russell L. Dicks pointed out the fact that there are four situations in the sickroom which afford the pastor his greatest pastoral opportunity.". He should call upon as many of his people who are sick as he can but he should call more frequently

17John Caldwell Thiessen, Pastoring the Smaller Church (Grand Rapids: Zondervan Publishing House, 1962), pp. 91-92.

${ }^{18}$ Dolloff, op. cit. pp. 95-98. 
and persistently upon persons going through these experiences."19 These situations are the surgical operation, one facing life with a physical handicap, the long convalescence, and one facing death.20 The ones facing surgery and the one facing death are considered under the following section on procedure. The handicapped and the long convalescent are dealt with in chapter six.

Show no partiality. It is true that the degree of a pastor's attention to one who is ill varies according to the seriousness of the illness, 21 but when the emergency ceases the frequency of the calls must also decrease. As Hampton Adams stated:

-. Nothing is more fatal to a pastor's influence than to give more attention to some people than to others when the needs are about the same. A man with a pastor"s heart simply will not manifest favoritism. ...22

When to Call

Call promptly. Eugene Dolloff suggested:

-. One of the surest ways to gain and maintain a reputation for personal integrity, and to retain and increase the love of one's people, is for the pastor to make it the rule of his life to respond immediately to all known cases of illness. Leave everything and gol ...23

19 Russell L. Dicks, Pastoral Work and Personal Counseling (New York: The Macmillan Co., 1945). p. 35.

20 Ibid., pp. 35-40. 21 Blackwood, op. cit.. p. 102.

22 Hampton Adams, The Pastoral Ministry (New York: Cokesbury Press, 1932). p. 69.

23Dollorf, op. cit., p. 98. 
The pastor must always be willing to visit the sick at any time he is called. Although it may not be necessary, this willingness must extend even into calling in the middle of the night if necessary. As Theodore L. Cuyler stated: ". - a pastor should be as quick to hasten to the room of sickness, as an ambulance is to reach a scene of disaster." 24

\section{Determine calling frequency. Really, a set rule cannot be} established as to how often to call on the sick, but generally one could say that a call should be made as often as the particular case may require. Sometimes an illness might require a daily visit or even several calls on the same day. ". . Good judgment, when coupled with divine direction, will furnish an infallible guide. . "25 The pastor should also try to discover what are the especially trying times for the patient and make an effort to be with the patient then. 26 This factor would also be a guideline in determining calling frequency.

Be considerate of visiting hours. When calling upon the sick in a hospital, it was most often suggested that visiting hours should be observed by the pastor unless previous arrangements have been made. 27

24 Theodore L. Cuyler, How to Be a Pastor (New York: The Baker and Taylor Co., 1890), p. 36 .

25Dolloff, op. cit. p. 113. 26 Cabot and Dicks, op. cit., p. 26.

27 Richard Hubacek, "Hospital Visitation," Vital Christianity, XC (September 6, 1970), 4; Thiessen, op. cit.. p. 97. 
Only one source suggested not to call during the scheduled visiting hours as the pastor can visit any time but the friends and relatives cannot. 28 Therefore, the pastor should make it a general rule to abide by visiting hours unless an emergency arises. If he must call at another time, he should then make himself known to the proper hospital staff member as a pastor, and then consult their permission to see the patient.29 Nolan B. Harmon sumarized and stated well the main guideline to be followed regarding this matter:

- . The rules of a hospital should be scrupulously regarded. Usually the minister is permitted some latitude as to hours of visiting, but he should let this permission come from the proper authorities and not take it for granted. 30

\section{PROCEDURE OF PASTORAL CALIING ON THE SICK}

"It is the pastor's responsibility to make his visits to the bedside of the sick so meaningful that a family will call the pastor for their loved one just as they summon their physician. . "31 The success of the pastor's calling on the sick may be increased or lessened by his calling procedure. The procedure of pastoral calling on the sick is considered under these four areas: entering the sickroom, directing

28 Lloyd Merle Perry and Edward John Lias. A Manual of Pastoral

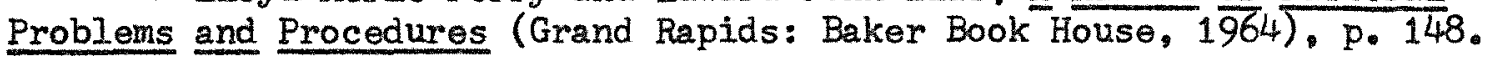

29David E. Sparks, "The Pastor and Hospital Visitation," The Nazarene Preacher. XIII (October, 1967), 12; Thiessen, Ioc. cit.

30 Nolan B. Harmon, Ministerial Ethics and Etiquette (New York: Abingdon-Cokesbury Press, 1928), p. 107 .

${ }^{31}$ Adams, op. cit., p. 66. 
the call in the sickroom, terminating the call in the sickroom, and particular cases needing special consideration.

\section{Entering the Sickroom}

Approach the sickroom. If the one who is $i l l$ is in a hospital, the pastor must first consider proper hospital etiquette. This involves making himself known at the front desk, finding out hospital regulations, inquiring at the desk the number of the patient's room if not already known, speaking to the nurse in charge on the proper floor. 32 It is also a good policy not to enter any room where the door is closed without first finding out something of the circumstances which exist behind the door. "No Visiting" and "Isolation" signs hanging on the door should be observed unless permission to enter has been granted by the nurse in charge. 33

Whether the pastor be visiting an ill person at home or in the hospital, he should find out from the family or from the nurse the essential facts about the patient's illness and how the patient has been during the last twenty-four hours. Richard Cabot and RusselI Dicks have suggested that it may be well to "take an opportunity to ask the doctor's advice about how you can best help the patient and let the

32 Blackwood, op cit. p. 104.

33 Richard K. Young, The Pastor's Hospital Ministry (Nashville: Broadman Press, 1954), p. 55 . 
doctor realize that you wish to forward his plans." 34

Size up the situation. Richard K. Young suggested that when one is visiting the sick he should "size up the entire situation at a glance during the process of entering the room. By this means alone one can determine to some extent what course the visit will take. . . 35 Before speaking a single word the pastor may gain valuable insight by simple observation. According to David E. Sparks,". The condition of the bed, the bedside table, the literature in use, the general appearance of the patient, facial expressionsmall are indications as to the structure of the call."36 This may be a simple principle: but if it is put into practice, it can prove invaluable in aiding the pastor in directing the call.

\section{Directing the Sickroom Call}

Set tone of the conversation. When the pastor calls on one who is sick, he must always keep in mind the purpose for which he is calling. He goes as a representative of Christ to let the one who is ill know that someone cares about him, particularly that". . God cares for him. suffers in his suffering, understands it, and plans for him in sickness as in health."37 Therefore, the pastor must not allow the call

${ }^{34}$ Cabot and Dicks, op. cit. p. 20. 35Young, op. cit., pp. 56-57. 36 Sparks, Ioc. cit. $\quad 37$ Cabot and Dicks, op. cit., p. 22. 
to become a pathological discussion. He need not ask detailed information about the nature of the illness nor suggest remedies. 38

Neither should the pastor interfere with the physician who cares for the patient by passing judgment on him or make a habit of sharing his own hospital experience or that of another with the patient. 39

When setting the tone of the conversation, it is also important to choose topics of discussion carefully, as Richard Cabot and Russell Dicks so ably stated:

When you choose topics exclude 211 that require close or prolonged attention or that range far from the interests that the sick man may be expected to keep alive despite his illness. Choose topics near him in space, time, and affection, and near the familiar subjects of his interest. His family and friends, his own past and future, objects in his own house or in his own room, his favorite hobbies and familiar tastes are the best starting points. 40

Avoid discussing depressing or alarming subjects. 41 Keep the conversation cheerful and optimistic. 42 When discussing spiritual matters, refrain from preaching as this builds walls of resentment. Instead, be considerate, understanding, and to the point, as you talk about God. God will do the rest. 43 Meet the person's needs at the individual

38 Reed, op. cit., p. 7; Dicks, How to Make Pastoral Calls, p. 10; Blackwood, op. cit., p. 108.

39 Lauterbach, op. cit., p. 39: Cabot and Dicks, op cit., p. 25: Young, op. cit. p. $5 \overline{7}$.

40 Cabot and Dicks, op. eit., p. 23. 41 Ibid., p. 24.

42 Lauterbach, op cit. p. 37; Perry and Iias, 1oc. cit.

43 Hubacek, op. cit. p. 3. 
spiritual level at which you find him. If the pastor is not sensitive to discovering the person's present spiritual condition and working from there, he may do more harm than good in his cal1. 44

While conversing one should also remember never to argue with the patient 45 and never become irritated or annoyed with the patient. 46 Instead, show an interest in the patient and his problems even if they seem to be smaIl and unimportant matters, 47 and encourage the patient. 48 The pastor must also avoid calling attention to himself or talking about himself and his pastoral calls. 49

Through conversation, the pastor must be sensitive enough to pick up clues to the actual needs on that day of the one who is ill.

In your first moments with the patient be as alert and as watchful as you can to pick up your clue to what is in his mind and to what has been there in recent hours:--hopes, disappointments, boredom, bitterness, irritability, or simply lassitude and blankness. .. 50

At times a sick person wants a visitor who will just chat for a few minutes without looking for a response, somewhat like a session of

${ }^{44}$ Cabot and Dicks, op. cit., p. 178.

45 Lauterbach, op. cit. p. 40; Harmon, op. cit. p. 104.

46 Lauterbach, op. cit., p. 38.47 Ibid.

48 Ibid., p. 40.

49 Blackwood, op. cit., p. 112.

${ }^{50}$ Cabot and Dicks, Ioc. cit. 
reading aloud. Some want the pastor to talk even though they cannot answer back. Still others may want only the friendly presence of someone without any conversation at al1.51 If the pastor recognizes these desires and obliges them, the call will be much more effective than if he follows a rigid premplanned technique.

An invaluable resource of the pastor worth mentioning at this point, is his ability to be an interested, sensitive, and interpretive listener. The less talking the pastor does, the better it is. Instead, he should listen to what is said and the way it is said. 52 Listening not only helps the patient express himself, but it helps the pastor to understand the patient. 53

When should we listen? Alwaysl Listen when you are in doubt, listen even when you are using other methods. Listen for your cues to be quiet, your cues for prayer, your cues to leave. The listening attitude brings the patient to the forefront of the picture. It makes him know you are interested in him, that you believe his fortunes important. . - You can win the appreciation of a patient by revealing interest in whatever claims his attention. 54

The pastor might also keep in mind that when working with the sick, listening may be either passive or directed. In passive listening one follows the patient wherever he takes you, and in directed listening one leads the patient to think and talk about a definite subject. 55

${ }^{51}$ Ioid., p. 24.

52 Chevis F. Horne, "The Minister's Resources in the Sick Room," Pastoral Psychology, XXII (April, 1971), 53.

${ }^{53}$ Cabot and Dicks, op. cit., p. $190 . \quad{ }^{54}$ Ibid.. p. 197. 55 Ibid. 
During the course of the call, the pastor should exhibit the grace of sympathy, 56 but keep in mind that sympathy can be given in a way that is harmful. ". . The sufferer should be made to realize that you share his pain; but if you dwell on his feelings you can unman him. . ."57 Bringing a sense of calmness and security by being the representative of the Great Physician would be more helpful than any other feeling expressed. 58

In considering what might or should take place in the course of a conversation with one who is 111 , there is one more thought to be considered. "The minister like the doctor must keep many secrets and hold much in reserve, but he must tell absolutely no lies to or about the sick. - "59 This guideline would apply particularly to one who questions whether he is going to get well. Eugene Dolloff suggested the pastor's answer to be somewhat as follows:

- Your physician is the only one who can even hope to give the right answer to your question. But we know that everything possible is being done for your recovery. Remember, you are in God's hands, and God never makes a mistake. Please co-operate with your doctor, your nurses, and with God. Cast your cares upon God, for he careth for you always. 160

Keep certain facts in mind. There are many "do's and don 'ts" and rules of which one needs to be awere when making a pastoral call on the

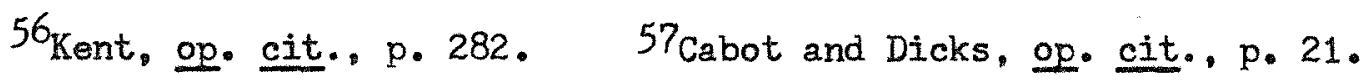
58 Harmon, op. cit., p. 103. 59 Cabot and Dicks, op. cit., p. 25. 60 Dolloff, op. cit., p. 108. 
sick. Due to the extensive number of them and their self-explanatory nature, they are presented in an enumeration form. The use of this method also aids greatly in their clarity and makes it easier for pastoral use.

1. Do not kick the bed in entering or leaving the sickroom. 61

2. Do not lean or sit on the bed. 62

3. Always allow the patient to take the lead in shaking hands.63

4. Stand or sit in line with the patient's vision so he is not required to move around in the bed.64

5. Move about quietly and gently in the sickroom. 65

6. Avoid loud talk or laughter. 66

7. Do not whisper or speak in low tones to a nurse, to a member of the family or to any one else in the sickroom or near it, if there is the slightest chance that the patient will see you or hear you. 67

8. Do not walk on tiptoe unless the patient is dozing or asleep or unless you know the patient prefers you to do so as it can be irritating and alarming. 68

9. Rarely, if ever, apologize for one's deficiencies such as the fewness of one's visits, or for anything else.69

10. Do not blame the patient for inattention or discourtesy if his eyes fall shut while you are speaking or reading. The drowsiness may be caused by drugs or sheer weakness.70

${ }^{61}$ Cabot and Dicks, op. cit., p. 22.

62 Ibid.; Perry and Lias, loc. cit.

63Young, op. cit., p. 57. 64 Ioid.; Perry and Lias, loc. cit.

65 Lauterbach, Ioc. cit.

66Perry and Lias, 1oc. cit.; Reed, 1oc. cit.

67 Cabot and Dicks, op. cit., p. 26.

68 Ibid. ${ }^{69}$ Ibid. p. 22.

70 Lauterbach, op. eit., p. 39. 
11. Do not be sensitive about ingratitude or being spurned by a patient. 71

12. Do not be afraid to smile.72

13. Leave the room if a doctor arrives while the pastor is there.73

14. Do not awaken a patient if he is asleep unless you first check with a nurse or responsible person. 74

15. Check with the nurse before opening windows, giving medication, or changing the position of the patient's bed.75

16. Generally, the pastor should leave when the patient's meal is served. 76

17. Be cheerful but not jovial. 77

18. The pastor should not visit when he is $i 11.78$

19. Never call attention to nauseating odors.79

20. When visiting a hospital ward with others lying near, speak to the other patients observing the visit. 80

21. Guard carefully confidences shared with you. 81

22. Do not carry emotional "germs" from one room to another. 82

23. Do not reveal negative omotional reactions through the voice, countenance, or manner. 83

24. Take all precautions to avoid having a woman patient become emotionally involved with the pastor; avoid touch, have a third person present, and always uphold the implied presence of a third person, God. 84

Terminating the Sickroom CaII

Keep call brief. Briefness should be a characteristic of the sickroom call. Often ten minutes is sufficient, particularly for those

71 Ibid., p. 40. $\quad 72$ Dolloff, op. citt., p. 107.

73 Hubacek, op. cit., 4.74 Tbid. 75 Ibid.

76Young, op. cit.. p. 60; Perry and Lias, loc. cit.

77Perry and Lias, loc. cit.; Blackwood, op. cit., p. 105.

78 Perry and Lias, loc. cit.: 79 Ibid.

${ }^{80}$ Harmon, op. cit., p. 108; Raymond Calkins, The Romance of the Ministry (Boston: The Pilgrim Press, 1944), p. 184.

${ }^{81}$ Reed, loc. cit. $\quad 82$ Young, op. cit., p. 58.

83 Ibid. $\quad{ }^{84}$ Cabot and Dicks, op. cit., pp. 172-73. 
seriously ill. The pastor can judge best by using good common sense and watching for signs of tiredness. 85 Few visits need exceed twenty minutes. 86 As Lauterbach so clearly stated: ". . Better a short visit that leaves the patient spiritually refreshed and eagerly looking forward to more, than one that is so long that it unduly tires him."187 This briefness not only prevents a strain on the patient, but it also impels the pastor to strive quickly to his main calling purpose and does not allow for this purpose to be blurred by the coming and going of many other visitors. 88

Incorporate Scripture and prayer wisely. Scripture and prayer are the pastor's indispensable tools in the sickroom." . . He will make use of them, even as the surgeon employs his varied, delicate instruments in the operating room. But the pastor is challenged to exercise equal skill in the use of his tools." 89

Chevis F. Horne suggested that the sick person wants to find something unshakable in which he can put his faith, and that something is God's holy Word.90 Scripture passages should be selected with great care, prior to the call, keeping the patient's needs in mind. Passages

$$
\begin{aligned}
& \text { 85 Hubacek, loc. cit. } 86 \text { Cabot and Dicks, op. cit., p. } 21 . \\
& 87 \text { Lauterbach, op. cit., p. } 21 . \\
& 89 \text { Dolloff, op. cit., p. } 109 . \\
& 98_{\text {Horne, op. cit.. p. } 52 .}
\end{aligned}
$$


telling of God's love, care, forgiveness, healing, and providence are best. 91 It is usually best to quote Scripture rather than read it as this tends to become mechanical, awkward, and even ineffective.92 ". . The fact that great passages of Scripture lie in the memory of the minister causes the people to feel that their truth is important to his life and to his ministry. .."93

Almost always prayer will be offered in the sickroom before leaving. Prayer is a tremendous pastoral resource as Richard Cabot and Russell Dicks indicated:

- Prayer is the minister's greatest single method in work with the sick. It is not the one he will use most often, or the one which should be most helpful to him in understanding his task. Prayer is the method which is most satisfactory in extreme crises; that which may be gained through it is most needed in the sickroom at all times; it is uniquely the minister's greatest method. 94

The pastor must not pray "off the surface of his mind," but pray thoughtfully keeping the particular patient and his needs uppermost in his mind.95 It has been suggested that prayer in the sickroom contain three elements: (1) application--recognize the patient's needs and express his thoughts about them, (2) reach--point beyond the immediate situation so the patient can feel the permanence of God, and (3) be in

91 Ibid. $\quad 92$ Dolloff, loc. cit.

93 Adams, op. cit., p. 68.

${ }^{94} \mathrm{Cabot}$ and Dicks, op. cit., p. 234.

95Dolloff, op. cit., p. 110. 
the language of religion-mit is simple, straightforward and rich in meaning.96 The prayer should be short and spoken in a conversational tone of voice.97 If the prayer is being offered in a hospital ward, Richard Young suggested that one can either call the other patient"s attention to the fact that prayer is being offered and pray with them all, or one could continue in the same tone of voice and pray only with the individual.98

\section{Consider offering communion. Particularly during an extended} illness, a patient may request to be administered communion. If such is the case, the pastor should by all means do so before the call is terminated. The main thing is that it be the patient's genuine desire that dictates its administration and not just the pastor's idea or the family request. 99

\section{Calling on Persons Needing Special Consideration}

The pre-surgical case. Anyone who has had surgery knows of the sense of tension one encounters before going into surgery. The pastor must be well aware of this fact and minister to the pre-surgical patient. The patient is likely to have anxieties concerning unknown and

${ }^{96}$ Cabot and Dicks, op. cit., pp. 220-23.

97 Young, op. cit., p. $68 . \quad 98$ Ibid.

99David Belgum. Clinical Training for Pastoral Care (Philadelphia: The Westminster Press, 1956), p. 75; Dolloff, op. cit. p. 115. 
unpredictable situations which need relieved. Realizing these things, the pastor should go to see the patient the night before surgery. During this call the pastor may quietly and confidently discuss the experience of the morrow, suggesting the relief which comes from knowing the operation has been performed and the journey back to good health has begun. In this way the pastor is able to do much to fortify and prepare the patient for the ordeal.100 By all means the pastor should pray. Richard T. Hughes in his article, "Spiritual Crises Facing Surgical Patients" made the following comments concerning prayer at this point:

A few words are in order here regarding prayer for petients prior to surgery. Since almost all patients do not want to undergo surgery and are fearful of it, a prayer invoking God's blessing and protection is both reassuring and conforting. Moreover, it is well to state precisely the patient's situation in the prayer. This enables him to come to grips with what is about to occur, and it also indicates to him that someone else fully understands. . . 101

Operations are generally performed in the early morning, except in cases of emergency. It is important, then, that the pestor arise early to see the patient on the morning of surgery. The patient may already be groggy from anesthetic, but will appreciate the call just the same. ". The fact that the pastor cared enough to make this extra

100Dolloff, op cit., p. 111; cf. Young, op. cit., pp. 95-97.

${ }^{101}$ Richard T. Hughes, "Spiritual Crises Facing Surgical Patients," Pastoral Psychology, XXII (December, 1971), 30. 
effort, registers deeply and favorably with the patient and his family. - "102 After the operation, the pastor should return to check on the patient.

The unconscious. The pastor may, occasionally during his ministry, be faced with the problem of calling upon one who is unconscious. What should he do in such cases? William A. Lauterbach suggested the following procedure for such cases:

- - step to the bedside and address the patient with a loud, clear voice to see whether there is any sign of recognition,... Even if there is no sign of recognition the pastor should recite a few Scripture verses and offer a prayer. . . Another thing which can be done for the unconscious patient is to make intercession for him. This may be done by the pastor alone, or he may ask those who are present to join the intercession. ..103

The pastor should always assume that the unconscious patient can hear and understand what is being said. Therefore, he should not whisper or say anything that he would not want the patient to hear. 104

The one with a communicable disease. The pastor must not neglect to visit those who have communicable diseases. Because the sufferer is quarantined against all outsiders except the hospital staff, the pastor"s call is even more important. However, the pastor needs to exercise good judgment by taking the same kind of precautionary measures as the physician and nurses take. James A. Beebe stated well the position the 102Dolloff, op. cit., p. 112. 103Lauterbach, op. cit., p. 31. 104Belgum, loc. cit.; Cabot and Dicks, op. cit.. pp. 309-10. 
pastor ought to take regarding visiting one with a communicable disease:

The conduct of the pastor in the face of contagious disease will be regulated largely by the laws of public health. He has no more right to consider personal danger than a physician; and his family is obligated to take the same risks should occasion arise, which are run by the doctor's wife and children. But let him be guilty of no foolhardiness. If he must expose himself to contagion in the discharge of his pastoral duties, let him consult a physician concerning protective measures which may be taken, both for his own and his family's sake. He should never be guilty of disregarding quarantines without the consent of health officials. The telephone and mails, of course, may be used to communicate with those who are isolated.105

Having taken all known precautionary measures, the pastor must place the rest in God's hands and rest assured that God will take care of him.106

The dying. The pastor should consider it a great honor and sacred opportunity to participate in the last moments of an individual's life. The pastoral call on the dying, especially being with the patient at the time of death, is the most difficult of pastoral ministries; however, if the pastor shirks away from this ministry, he is bound to feel a sense of guilt.107 Not only that, shirking this duty may cause the church to lose families as Eugene Dolloff indicated: ". . Failure of the pastor before and after the bereavement results in the loss of a surprisingly large number of people from churches."108

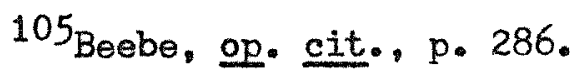

106 Blackwood, op. cit., p. 111; Kent, op. cit., p. 284.

107Young, op. cit., p. 110 .

${ }^{108}$ Dolloff, op. cit. p. 116. 
The pastor should consider it a rare privilege to think beyond physical existence with the one who is dying, to think with him through any regrets that he may have of going, to reassure him in regard to his family, to bring the presence of Christ to him, and to strengthen him by one's own poise and faith in God in the presence of death. These are needs that the dying person may have; the better one knows the patient the more effectual such a ministry will be.109

Richard K. Young stated eight suggestions for the pastor in ministering to the dying. These suggestions were:

1. Possess a strong religious confidence in God"s loving and forgiving spirit, as revealed by jesus.

2. Make contact with the patient before a crisis is reached in order that a larger service may be rendered.

3. Make short, frequent visits, as the dying person often gets lonely.

4. Avoid showing signs of grief, and help the family to do the same.

5. Let the patient take the lead in discussion of religious matters.

6. Be alert for any signs on the part of the individual that indicate a desire to confess secret sins.

7. Use directed listening and quiet for one who fears death.

8. Do not whisper inside or outside the room.110

The sick or injured child. The pastor has the responsibility to minister unto the little ones in need as well as the adults. Pastoral calling on the sick or injured child is important both to the child and to his parents. In many cases, especially when the child is an infant, the pastor must strengthen, comfort, and console the parents and pray for the child. The expression of sympathy to the parents does not

${ }^{109}$ Cabot and Dicks, op. cit., p. 305. 110 Young, loc. cit. 
suffice when their child is seriously ill. William A. Lauterbach suggested that intercessory prayer should be employed at the bedside of the sick infant. The sick infant "should be commended to the loving care of the merciful Father in heaven, without any attempt to bend or force the will of God to that of the parents or other relatives.111

The mentally ill. The pastor must minister unto all the sick including those sick mentally. Eugene Dolloff made the following pertinent comments concerning pastoral calling on the mentally ill:

- Unless a patient has been adjudged by competent medical men to be hopelessly insane, and has been placed permanently in a hospital for the insane. I fully believe the pastor is honor bound to call on him. These unfortunate people will be found in every parish, and most certainly they warrant pastoral consideration and care. Calls made upon patients at institutions will require large blocks of time. for often these hospitals are located at a considerable distance. It frequently happens that an alert pastor can make large contributions toward the recovery of those who temporarily are sick mentally Some of our most progressive neurologists have discovered this fact. 112

The importance of calling on those who have suffered or are now suffering from mental illness was well stated by Wiliiam A. Lauterbach: ". - If ever a patient needs good spiritual counsel and sympathetic understanding, it is when he goes through the process of adjustment to normal living after a siege of mental illness. . .113

$$
\begin{aligned}
& 111_{\text {Lauterbach, loc. cit. }} \\
& 112_{\text {Dolloff, op. cit., p. } 114 .} \\
& 113_{\text {Lauterbach, op. cit., p. } 45 .}
\end{aligned}
$$


TV. POSSIBLE RESULTS OF PASTORAL CALLING ON THE STCK

The results of pastoral calling on the sick are not predictable in every case. Many of the results desired are simply the purposes being fulfilled. Homer A. Kent presented four results or benefits of the sickroom ministry: (1) will strengthen the faithful, (2) restores the careless, (3) will reach the unsaved, and (4) develops the pastor's sympathetic nature. 114 Willis A. Reed in his article. "The Pastor and Sick Visitation," stated the possible result of calling on the sick in the following way:

Faithful visitation of the sick and those who suffer sensitizes our witness for Christ in such a way as to make those who are ill more conscious than ever that we are made for God and each other. - - Any pastor can and will be a blessing to his people if he is faithful, regular, and kind in his visitation. 115

\section{PASTORAL RESOURCES FOR CAILING ON THE SICK}

Devotional literature for one who is ill can be very helpful.

Chaplain Malcolm B. Ballinger suggested seven reasons why this is true:

1. It is symbolic of Christian faith.

2. It is tangible, capable of being touched.

3. It is available when needed by the patient.

4. It can direct the thinking and feeling of the patient when he may be too listless to direct himself.

5. Good devotional literature can answer some questions and help the patient accept his situation and himself.

6. He can share his pamphlet with others, which helps foster interpersonal relations.

114 Kent, op. cit., pp. $285-86$.

$115_{\text {Reed, op. cit. } 7 .}$ 
7. It may help the patient verbalize his feelings to the chaplain.116 When selecting material for one who is ill, the patient's needs must be considered, anticipate how he may interpret the content, and select material appropriate for the patient's future. Also, consider his physical, mental, educational, and spiritual capacity.117 The material should be kept short except for one who is chronically ill. The seriously ill may need no more than a single Scripture passage or hymn verse prepared in large easy-to-mead type.118

The remainder of this section will include actual sample resources the pastor could use in the sickroom. Books for pastoral reference are suggested; titles of pamphlets to give to the patient are given; and Scripture verses, hymns and poems are indicated. The suggested material is by no means exhaustive. However. It gives the pastor something to "go on" as he prepares and makes plans before entering the sickroom. Other Scriptural passages in particular might well be added according to the pastor's personal desires and those favorite passages of the one whom he is to visit.

\section{Pastoral References}

1. Edmond Holt Babbitt. The Pastor's Pocket Manual for Hospital and Sickroom. New York: Abingdon-Cokesbury Press, 1949.

$116_{\mathrm{Ma}}$ lcolm B. Ballinger, "Devotional Iiterature for Patients," Bulletin of the American Protestant Hospital Association (April, 1951). cited by Belgum, op. cit. p. 54.

117 Belgum, loc. cit. 118 Lauterbach, op. cit., pp. 23-24. 
2. Russell L. Dicks. Comfort Ye My People: A Manual of the

Pastoral Ministry. New York: The MacmiII an Company. 1947.

3. Russell L. Dicks. Meditations for the Sick. Chicago:

Willett, Clark and Company. 1937.

4. Russell I. Dicks. Thy Health Shall Spring Forth. New York:

The Macmilian Company, 1946.

5. William A. Lauterbach. Ministering to the Sick. St. Louis, Missouri: Concordia Publishing House, 1955.

\section{Pamphlets to Give to the Patient}

1. Warner Press. Anderson. Indiana. \$.25 each

"God at My Bedside" by Eugene L. Mendenhall, Jr.

"God"s Compassion"

"God's Sufficiency"

"God"s Peace"

"Faith"

2. Beacon Hill Press. Kansas City, Missouri. \$.25 each

"Now that IIIness Has Come" by Ernest E. Grosse

3. Moody Press. Chicago. \$.15 each

"Comfort for Troubled Christians" by J. C. Brumfield

4. Helen Steiner Rice Poem Booklets. Gibson Inspirational Cards. $\$ 1.00$ each

"Prayers and Meditations"

"Just for You"

5. Hallmark Booklets. $\$ .60$ each

"Treasures of Cheer"

"Beautiful Thoughts"

"Meditations by Peter Marshall"

"Look to This Day"

"Bright Horizons"

\section{Poems and Thoughts}

Just as there comes a warm sunbeam into every cottage window, so comes a love-beam of God's care and pity for every separate need. - Nathaniel Hawthorne

(Taken from Clyde Francis Lytle (ed.), Leaves of Gold, p. 13.)

"The Lord Will Care"

Let all who are sad take heart again;

We are not alone in our hours of pain;

Our Father stoops from His throne above

To soothe and quiet us with His love;

He leaves us not when the storm is high;

And we have safety, for $\mathrm{He}$ is nigh; 
Can there be trouble, which He doth not share?

0 , rest in peace, for the Lord will care.

--Marianne Farmingham

(Taken from Arthur and Nancy Delioss (eds.), The Gold Star Family

Album. p. 120.)

"He Giveth More"

He giveth more grace when the burdens grow greater,

He sendeth more strength when thelabors increase;

To added affliction He addeth His mercy,

To multiplied trials, His multiplied peace.

When we have exhausted our store of endurance,

When our strength has failed ere the day is half done,

When we reach the end of our hoarded resources,

our Father's full giving is only begun.

His love has no limit, his grace has no measure,

His power no boundary known unto men;

For out of his infinite riches in Jesus

He giveth and giveth and giveth again. -Annie Johnson Flint

(Taken from James Gilchrist Lawson (comp.), The Best Loved Religious Poems, p. 189.)

"There Are Blessings in Everything"

Blessings come in many guises

That God alone in love devises,

And sickness which we dread so much

Can bring a very "healing touch" --

For often on the "wings of pain"

The peace we sought before in vain

Will come to us with "sweet surprise"

For God is merciful and wise--

And through long hours of tribulation

God gives us time for meditation.

And no sickness can be counted loss

That teaches us to "bear our cross."

- Helen Steiner Rice

(Taken from an Inspirational Card by Gibson.) 
"The Way to God"

If my days were untroubled and my heart always light

Would I seek that fair land where there is no night;

If I never grew weary with the weight of my load

Would I search for God's Peace at the end of the road;

If I never knew sickness and never felt pain

Would I reach for a hand to help and sustain;

If I walked not with sorrow and lived without loss

Would my soul seek sweet solace at the foot of the cross;

If all I desired was mine day by day

Would I kneel before God and earnestly pray;

If God sent no "Winter" to freeze me with fear

Would I yearn for the warmth of "Spring" every year;

I ask myself this and the answer is plain--

If my life were all pleasure and I never knew pain

I'd seek God less often and need Him much less,

For God's sought more often in times of distress,

And no one knows God or sees Him as plain

As those who have met Him on "The Pathway of Pain."

(Taken from an Inspirational Card by Gibson.)

Scripture Verses (King James Version)

II Cor. 4:17 Our light affliction, which is but for a moment, worketh for us a far more exceeding and eternal weight of glory.

Phil. 4:11 I have learned, in whatsoever state I am, therewith to be content.

Joshua 1:5,6 I will be with thee; I will not fail thee nor forsake thee. Be strong and of a good courage.

PsaIms 27:14 Wait on the Lord; be of good courage, and He shall strengthen thine heart; wait. I say, on the Iord.

Psalms 34:19 Nany are the afflictions of the righteous: but the Lord deliveroth him out of them all.

Psalms 46:1 God is our Refuge and Strength, a very present Help in trouble.

Psalms 46:10 Be still and know that I am God.

Psalms 55:22 Cast thy burden upon the Lord, and He shall sustain thee.

Psalms 73:26 Ny flesh and my heart faileth; but God is the Strength of my heart, and my Portion forever. 
Isaiah 40:29 He giveth power to the faint; and to them that have no might $\mathrm{He}$ increaseth strength.

James 4:8 Draw nigh to God, and He will draw nigh to you.

Psalms 23:1 The Lord is my Shepherd; I shall not want.

Psalms 145:14 The Lord upholdeth all that fall, and raiseth up a.l those that be bowed down.

Neh. 8:10 The joy of the Lord is your strength.

Isaiah 40:31 They that wait upon the Lord shall renew their strength; they shall mount up with wings as eagles; they shall run and not be weary; and they shall walk and not faint.

(For the dying)

Psalms 23:4 Yea, though I walk through the valley of the shadow of death. I will fear no evil; for thou art with me; thy rod and thy staff they comfort me.

Psalms 27:1 The Lord is my Light and my Salvation; whom shall I fear? The Lord is the Strength of my life; of whom shall I be afraid?

John 6:40 And this is the will of Him that sent Me, that everyone which seeth the Son and believeth on Him may have everlasting life; and $I$ will raise him up at the last day.

Rom. 8:18 I reckon that the sufferings of this present time are not worthy to be compared with the glory which shall be revealed in us.

Rom. 14:8 Whether we live, we Iive unto the Lord; and whether we die, we die unto the Lord; whether we live, therefore, or die, we are the Lord's.

Hebrews 13:5 I will never leave thee, nor forsake thee.

Rev. 21:7 He that overcometh shall inherit all things; and I will be his God, and he shall be my son. 


\section{CHAPTER IV}

PASTORAL CALLING ON THE BEREAVED

The ministry to the bereaved, one who has lost a loved one, is another very important phase of the pastor's calling program. In fact, as Russell L. Dicks put it: ". More people seem to be lost to the church because of the failure of the minister in bereavement than at any other time."1 Therefore, the pastor must carefully consider how his ministry to the bereaved can most effectively be fulfilled.

The material is presented under five divisions: purposes of pastoral calling on the bereaved, preparation for pastoral calling on the bereaved, procedure of pastoral calling on the bereaved, possible results of pastoral calling on the bereaved, and pastoral resources for calling on the bereaved.

\section{PURPOSES OF PASTORAL CALIING ON THE BEREAVED}

William F. Rogers related six needs of the bereaved in his article, "The Pastor's Work with Grief." They were: the need for the support of others, the need for the actualizing of loss, the need to express sorrow, the need for verbalization of hostility, the need for verbalization of guilt feelings, and the need of establishing new

${ }^{1}$ Russell L. Dicks, Pastoral Work and Personal Coungeling (Now York: The Macmillan Company, 1945), p. 42 . 
relationships. 2 In order to meet these needs, purposes of pastoral calling upon the bereaved must be established and kept clearly in mind as the pastor calls.

The first purpose of the call is to comfort and to console the bereaved in his time of grief.3 By just being with the person in grief and letting him know someone cares, one could accomplish this purpose. Secondly, the pastor should offer the person strength to accept the situation by pointing out to him the hope of heaven and the kindness of the Shepherd, Jesus Christ. 4 By calling with these two purposes in mind, the pastor has done much to help meet the six needs of the bereaved.

\section{PREPARATION FOR PASTORAL CALLING ON THE BEREAVED}

\section{Personal Pastoral Preparation}

Wuch of the discussion in the section on preparation in chapters two and three would also be applicable in calling on the bereaved, particularly in regard to spiritual and physical preparation. Consequently. it is not repeated; but there are some additional preparatory concerns to be remembered when calling on the bereaved, particularly under mental preparation.

2William F. Rogers, "The Pastor's Work with Grief." Pastoral Psychology, XIV (September, 1963), 22-25.

${ }^{3}$ Andrew W. Blackwood. Pastoral Work: A Source Book for Ministers (Philadelphia: The Westminster Press, 1945), p. 120.

Inid. pp. 120-21. 
When preparing to make a call on one who is bereaved, the pastor should stop and make the following consideration:

The clergyman's ministry to the bereaved is limited by his parishioner"s feelings toward him. If the pastor has failed in his ministry to the one who has died, particularly if that failure was due to his not calling during the illness, then his ministry to the family is apt to be ineffective. . . 5

The pastor's ministry to the bereaved is determined a great deal by his previous relationship to that person or persons. The closer he has becone to them previously, the greater help he can be during bereavement. Richard K. Young emphasized that ". . the pastor occupies one of the most strategic positions in society for helping bereaved families get started into a healthy state of bereavement and thus avoid later morbid reactions..." 6

In making mental preparation for calling on the bereaved, the pastor must be aware that there are common stages through which one who is bereaved passes. George C. Bonnell listed them as follows: numbness or shock, fantasy or denial, guilt and recrimination, grief, adjustment, and acceptance.7 Also, Russell L. Dicks suggested another common occurence in the bereaved:

- Many of the questions and thoughts which arise in the minds of the bereaved have to do with things which are beyond the common

5 Dicks, loc. cit.

6Richard K. Young, The Pastor's Hospital Ministry (Nashville: Broadman Press, 1954), p. $\overline{115}$.

"George C. Bonnell, "The Pastor's Role in Counseling the Bereaved," Pastoral Psychology, XXII (February, 1971), 28-33. 
mind, that is, they deal with God's justice, God's nature, and the nature of heaven. This is the clexgyman's area of work and thinking. 8

By realizing that the bereaved do pass through different stages of bereavement and have certain thoughts, the pastor is better prepared to assist constructively in his call on the bereaved.

In making final preparation to call on the bereaved person, Richard Hubacek in his article, "When Death Comes," suggested asking yourself several questions. The answers given to them would largely determine the course of action to follow and give a better understanding of what is needed. These questions are: What kind of help is needed most? physical? spiritual? What kind of help can you offer best? Was this a sudden or unexpected death? Was there a long period of suffering which has left family members mentally and physically exhausted? Is this a closely knit family? Do they have a deep faith in God? Was the deceased a Christian?

When to $\mathrm{CaII}$

Immediately upon receiving word of a death of a parishioner, the pastor should call at the home or the hospital unless he is specifically requested not to call.10 If he should call at the home and find that

\section{${ }^{8}$ Dicks, 1oc. cit.}

9Richard Hubacek, "When Death Comes," Vital Christianity, XCII (January 23, 1972), 5.

10Dicks, op. cit., p. 43; cf. John C. Thiessen, Pastoring the Smaller Church (Grand Rapids: Zondervan Publishing House, 1962), p. 93. 
the one whom he calls to see does not care to receive him or anyone else, he should still make his presence known at the door and offer to do anything he can to help.11 If it is an expected death due to a long illness, the pastor should try to be present at the actual time of death as the pastor's presence symbolizes a great deal to the bereaved.12

III. PROCEDURE OF PASTORAL CALLING ON THE BEREAVED

In considering the procedure of the pastoral call on the bereaved, the material is divided into three sections: directing the call, torminating the call, and continuing to call.

\section{Directing the Call on the Bereaved}

Be considerate. When calling on the bereaved in the home, remember that you are a guest of a very needy family and should act accordingly. Many tensions are in existence and emotions are much in evidence, so the pastor should not feel hurt if anger or any feelings of hostility are directed toward him.13 Any personal frustrations or problems on the pastor"s part should be left at the door.14 Excessive

${ }^{11}$ Nolan B. Harmon, Ministerial Ethics and Etiquette (New York: Abingdon-Cokesbury Press, 1928), p. 110.

12 Bonne11, op. cit. 34.

13 Hubacek, op. cit., 6; cf. Bonnell, op. cit., 35.

${ }^{14}$ Hubacek, 1oc. cit. 
consolation should be avolded; and above all, cheap, superficial consolation should never occur.15 In this first, immediate visit, generally no attempt should be made on the pastor's part to arrange for the funeral. 16

The pastor must also consider the length of his visit:

A good rule to follow is, don't stay too long. This, of course, changes with each situation. Fifteen minutes is usually long enough. Remember, that others also will be coming frequently. The family needs some privacy to have time to think and work out last-minute details. By overstaying, added pressure results because of things which need to be done.1?

Help bereaved through stages of grief. As discussed earlier in the section on preparation for pastoral calling on the bereaved, there are several common stages through which most bereaved people pass: numbness or shock, fantasy or denial, guilt and recrimination, grief, adjustment, and acceptance. In addition to knowing what they are, the pastor should know how to assist the bereaved in each of the stages. In the stage of shock, the pastor should be with the person, drawing him out and encouraging him to vent his emotions.18 At this stage, the family should be helped not to feel guilty if they feel a certain sense of relief instead of entirely sorrow, particularly if the death followed

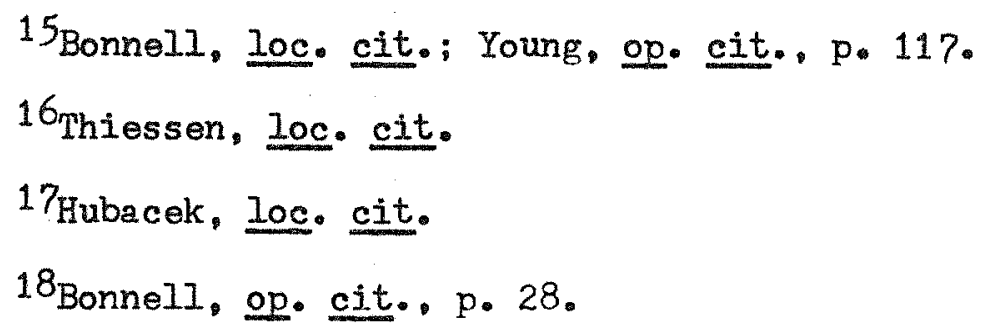


an extended illness.19 In the second stage, denial, the pastor "... will gently elicit memories that carry great emotional impact to the bereaved. - "20 The third stage, guilt, should be carefully observed by the pastor. These emotions may be directed toward oneself, the deceased, other people, or God. The pastor should allow the feelings to be expressed but should watch for guilt that is not natural, but neurotic. 21 Through the last three stages-mgrief, acceptance, and adjustment--the pastor will do best by being patient and being a good listener and friend.22

Remember that it takes a long. long time (if ever) to arrive at the final stage of bereavement. When death is expected, this period could be lessened if the pastor would begin work with those who will experience the loss before the death occurs.23 "Finally, beware of danger signals. When they are evident, consult a specialist and prepare the bereaved for a professional referral. . . 24

\section{Terminating the Call on the Bereaved}

Much help for the bereaved can come from the sharing of the pastor's faith through prayer and Scripture. "The pastor should pray

${ }^{19}$ Richard C. Cabot and Russell L. Dicks, The Art of Ministering to the Sick (New York: The Macmillan Company, 1942), p. 315 .

20 Bonnell, op. cit., p. 29. 21 Ibid., pp. 29-30.

22 Ibid., pp. 30-33, 36; Hubacek, loc. cit.

23Bonnell, op. cit., 34 .

24 Ibid.. p. 36. 
with the family when the relationship indicates that prayer would be appropriate. - ."25 This prayer is for the purpose of commending the spirit of the loved one to God's care and to remind the bereaved that God cares for them, which is often forgotten in the time of bereavement.26 Sometimes things that cannot be mentioned djrectly can be spoken of in prayer.27 It might be difficult with all the excitement and confusion to read from the Bible, but a few appropriate words quoted from the Scriptures would be very helpful. 28

Through personal words in addition to prayex and Scripture, the pastor can also share his faith. Of particular comfort would be any parts of conversations which the pastor may have had with the patient.29 When planning the funeral service, opportunities can also open up to recall to mind what elements of faith concern life beyond death. 30

\section{Continuing to $\mathrm{Call}$ on the Bereaved}

The comforting spirit and words of the pastor are even more necessary after the funeral than before. This is the time of greatest opportunity for the pastor, as it is in the immediate days that lie ahead

\footnotetext{
25Young, op. cit., p. 118. 26 Dicks, op. cit.. p. 44.

27Bonnell, op. cit. 35. 28 Thiessen, loc. eit.

29 Young, loc. cit.

30 John Charles Wynn, Pastoral Ministry to Families (Philadelphia:
} The Westminster Press, 1957), p. 66. 
when Ioneliness lays heaviest on the bereaved. 31 John Wynn, in his ministry, found it to be especially comforting to return to the home the very next Sunday after the death occurred and lead the family in a quiet worship. He also found that calls on succeeding holiday seasons when memories really become vivid were of great comfort. 32 Gradually, these visits on the bereaved can be spaced out at Ionger and Ionger intervals, but never make the mistake of forgetting about them after the first initial visit. 33

IV. POSSIBLE RESULTS OF PASTORAL CALLING ON THE BEREAVED

The first possible result of pastoral calling on the bereaved would be having helped one to successfully pass through all the stages of bereavement and arrive at the final stage of acceptance. This would represent a long period of patient and spiritual guidance, but what a wonderful accomplishment it would be.

Secondly, if one calls on the bereaved with real concern and with God's guidance, new souls can be reached for the kingdom of God. 34 There could be no greater result ever accomplished.

31Harmon, 1oc. cit.; Dicks, op. cit., p. 47.

$32_{\text {Wynn, op. eit. p. p. } 69 .}$

$33 \mathrm{Harmon}$, op cit., p. 111.

${ }^{34}$ Hubacek, 1oc. cit. 
V. PASTORAL RESOURCES FOR CALLING ON THE BEREAVED

Because the written word can often bring comfort and new direction to one's life, the pastor should have in mind resources he could share when calling on the bereaved. Suggestions are made as to pamphlets which may be given to the bereaved, poems and thoughts which may be helpful, and Scriptural helps.

Pamphlets to Give to the Bereaved

1. Warner Press. Anderson, Indiana. \$.25 each "God"s Compassion"

"God"s Guidance"

2. Beacon Hill Press. Kansas City, Missouri. \$.25 each

"Now That Bereavement Has Come" by C. B. Strong

3. Helen Steiner Rice Poem Booklets. Gibson Inspirtational Cards. $\$ 1.00$ each

"Let Not Your Heart be Troubled"

"Prayers and Meditations"

4. Hallmark Booklets. $\$ .60$ each

"Treasures of Cheer"

"Meditations by Peter Marshall"

"Look to This Day"

"Bright Horizons"

\section{Pooms and Thoughts}

"Joy Cometh in the Morning" (Psalms 30:5)

There must be thorns amid life's flowers you know,

And you and $I$, wherever we may go.

Can find no bliss that is not mixed with pain.

No rain without a cloud. It would be vain

For me to wish that not a single tear

Might dim the gladness that you hold so dear.

I am not wise enough to understand

All that is best for you. The Master's hand

Must sometimes touch life's saddest chords to reach

Its sweetest music, and His child to teach

To trust His love, till the long, weeping night 
Is all forgotten in the morning light.

Trust--trust Him, then, and thus shall good or ill

Your trustful soul with present blessing fill.

Each loss is truest gain if day by day,

He fills the place of all He takes away.

- Message Balarat

(Taken from Arthur and Nancy DeMoss (eds.). The Gold Star Family Album, p. 125.)

\footnotetext{
"Death Opens the Door to Life Evermore" We live a short while on earth below. Reluctant to die for we do not know Just what "dark death" is all about And so we view it with fear and doubt, Not certain of what is around the bend We look on death as the final end To all that made us a mortal being And yet there lies just beyond our seeing A beautiful life so full and complete That we should leave with hurrying feet To walk with God by sacred streams Amid beauty and peace beyond our dreams -For all who believe in the Risen Lord Have been assured of this reward, So death is not sad . . it's a time for elation. A joyous transition.. the soul's emigration Into a place where the soul's Safe and Free To live with God through Eternity! - Helen Steiner Rice (Taken from an Inspirational Card by Gibson.)
}

"Life Is Foreverl Death Is a Dreaml" If we did not go to sleep at night We'd never awaken to see the light, And the joy of watching a new day break Or meeting the dawn by some quiet lake Would never be ours unless we slept While God and all His angels kept A vigil through this "little death" That "s over with the morning's breath -And death, too, is a time of sleeping, For those who die are in God's keeping And there's a "sunrise" for each soul. For life not death is God"s promised goal -So trust God's promise and doubt Him never For only through death can man live forever! - Helen Steiner Rice (Taken from an Inspirational Card by Gibson.) 


\section{Scripture Verses (King James Version)}

Psalms 23 The Lord is my Shepherd; I shall not want....

Joshua 1:5,6 I will be with thee; I will not fail thee nor forsake thee. Be strong and of a good courage.

Psalms 27:14 Wait on the Lord; be of good courage, and He shall strengthen thine heart; wait. I say, on the Lord.

Psalms 46:1 God is our Refuge and Strength, a very present Help in trouble.

Psalms 55:22 Cast thy burden upon the Iord, and He shall sustain thee.

Isaiah 66:13 As one whom his mother comforteth, so will I comfort you.

John 3:16 For God so loved the world, that he gave his only begotten Son, that whosoever believeth in him should not perish, but have everlasting life.

John 14:18 I will not leave you comfortless: I will come to you.

Rev. 14:13 Blessed are the dead which die in the Lord . . that they may rest from their labours; and their works do follow them.

I Cor. 2:9,10 Eye hath not seen, nor ear hear, neither have entered into the heart of man, the things which God hath prepared for them that love him. But God hath revealed them unto us by his Spirit.

John 14:2 In my Father's house are many mansions; if it were not so, I would have told you. I go to prepare a place for you.

Rev. 21:4 And God shall wipe away all tears from their eyes; and there shall be no more death, neither sorrow, nor crying, neither: shall there be any more pain: for the former things are passed away. 


\section{CHAPTER $V$}

PASTORAL CALIING ON THOSE WTTH SPECIAL NEEDS

\section{THE TROUBLED}

Pastoral calling on the troubled might involve many different types of situations and a variety of needs. The troubled person may be one who is Ionely, one who is discouraged, one who is dissastified, or one with a deep spiritual need. Often the sick, the bereaved, the aged and shut-ins may become troubled in that they are lonely or discouraged. However, because these cases were already considered in other chapters, only those troubled for other reasons than these are considered here.

One class of people who are troubled due to loneliness are the widows and maiden ladies who live alone. They definitely should not be neglected by the pastor, but extreme care must be taken in making such calls:

- A warm friendliness is in order, but extreme care should be used to keep within proper bounds. Someone in the community will soon notice it if the pastor makes frequent calls in a home where a woman lives alone, or is at home alone all day with no one else in the house. His visits may be perfectly in order, but the appearance is not good....1

Others might be troubled due to discouragement. Perhaps it is caused by an accident, a sudden illness, an unexpected bereavement, a

${ }^{1}$ John Caldwell Thiessen. Pastoring the Smaller Church (Grand Rapids: Zondervan Publishing House, 1962), p. 92 . 
financial distress, an emotional upset, or a threatened mental breakdown. It is experiences like this that drive some people to acts of desperation. The pastor needs to go to the discouraged person and attempt to learn some of the facts about the situation. Infinite tact on the pastor's part is required in such a call. As each case differs, it would be impossible to lay down an infallible rule of procedure. The pastor should, however, direct the person toward Christ and his teachings and counsel regarding their situation. The pastor really needs to enter into such a call with the divine guidance of God as it may only be through his wise counsel and prayer that the individual is brought out of his state of discouragement. 2

"If you are a sagacious "watchman," you will also be very prompt in giving attention to any case of difficulty or disaffection..." 3 Upon learning of any such case, the pastor should call at the earliest practjcable moment and have a frank and honest talk with the person. In just a few moments the pastor ". - may prevent that sore from festering. or may heal it on the spot. . . 14 Dealing with dissatisfied or offended people is not the pleasant part of a pastor's work, but the pastor must not shirk his duty merely because it is disagreeable. 5

${ }^{2}$ Ibid.

3Theodore L. Cuyler, How to Be a Pastor (New York: The Baker and Taylor Co., 1890), p. 24 .

Ioid., p. 25.

5 Ibid. pp. $25-26$. 
The final type of troubled person to be discussed in this section is the one who has a deep spiritual need. The pastor will often find in his work one who has ceased to take any active part in the work of the church and even some who have lost their interest in spiritual things. With this group of people the pastor should seek to establish friendship so that he may, if possible, lead them back to the ways of discipleship. First, he must win their confidence, and then he can learn their reasons for why they no longer serve. 6 The pastor will of ten find the person's chief problem to be an intellectual one. ". . They have become entangled in doubt, and either are, or suppose themselves to be, disabled for Christian service. - ."? Actually, many of these doubters who have withdrawn from active church work are not half so widely separated from their fellow parishioners as they think. ". . The wise pastor is often able to give great relief to burdened minds by showing them that the difficulties which had troubled them do not exist. 8

These are the special considerations one needs to make when calling on one who is troubled, whether it be due to loneliness, discouragement, dissatisfaction, or a spiritual need. Special details in regards to preparation and procedure can be found in chapter two.

6 Washington Gladden, The Christian Pastor and the Working Church (New York: Charles Scribner's Sons, 1910), p. 180.

7 Ibid.

${ }^{8}$ Ibid. . p. 181 . 
II. THOSE IN PRTSON

One who is in prison may be a church member, as they sometimes fall into deep sin, or he may be someone from the community who has no church connection.9 Calling upon such a person is a very difficult task, particularly if it is a parishioner in whom the pastor has had utmost confidence. However, the pastor must go.10 In preparing for the pastoral call to the prison, he must consider the purposes for his call, preparation he needs to make, the procedure he should follow, and the results which may occur.

\section{Purposes of Pastoral Calling on Those in Prison}

In calling on one who is in prison, the pastor should not only show the person he is their friend but should point them to a better way.11 It is his goal to help the prisoner stabilize himself by tapping his ow spiritual resources. 12

\section{Preparation for Pastoral Calling on Those in Prison}

In preparing to make a pastoral call on one who is in prison, the pastor should remember the following:

9Thiessen, op. cit., p. 95.

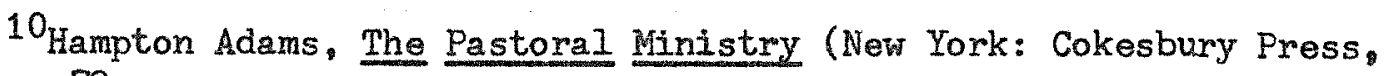
1932), p. 73 .

${ }^{11}$ Thiessen, loc. cit.

12 Harry J. Brevis, "Counseling Prison Inmates " Pastoral Psychology. VII (February, 1956), 37. 


\begin{abstract}
When visiting, writing, and representing the church, the pastor must keep in mind (although we oversimplify) that the majority of prisoners have two preoccupations: their case and their family. ...13
\end{abstract}

The need for outside contact is greatest for the prisoner at the beginning of his confinement. As he is stunned and bewildered by a totally new environment, contact between a prisoner and his pastor is welcomed by the prison.14 However, the pastor must remember that prison rules and regulations are more strict than those of the hospital and are carefully enforced. The pastor should know and observe these rules.15 Careful advance preparations must be made within the context of the rules of the prison. Every correspondent and visitor must be approved by the prison. 16

Approval procedures vary widely, but in general the prisoner should request to see his pastor and secure prison approval for him to visit. It is good for the pastor to take initiative by writing to the inmate, indicating interest in a visit. A copy of the letter might go to the chaplain. A letter from the institution is then sent granting permission for the pastor to write or visit. 17

Procedure of Pastoral Calling on Those in Prison

Set tone of the conversation. As the first visit to a prison might be rather uncomfortable; it might be helpful to make this call with the

13George C. Kandle and Henry H. Cassler. Ministering to Prisoners and Their Families (Philadelphia: Fortress Press, 1969), p. 59.

${ }^{14}$ Ibid. . pp. 59-60.

15 Nolan B. Harmon, Ministerial Ethics and Etiquette (New York: Abingdon-Cokesbury Press, 1928), p. 111; cf. Kandle and Cassler, op. cit., p. 60 .

16 Kandle and Cassler, Ioc. cit. 17 Ibid. 
prisoner"s family.18 Even if the prisoner does not receive the pastor kindly, it is worthwhile to make an attempt.19 When calling, the pastor must not preach or judge, condone or condemn; he can only assist. 20 one of the key techniques to be used when calling on the prisoner is that of listening. The pastor listens and then tries to reflect back to the prisoner a better understanding of his relations with the outside world, the people around him and their relations to him. 21

During the call, the pastor must be on his guard against minimizing the wrong this one in prison has done: ". We used to hear much in sermons about Christ's love for the sinner and his hatred of the sin. It is that attitude that the pastor must have when he visits an indicted or a convicted man." 22

Nolan B. Harmon suggested that persons in prison are often possessed with a mental attitude which causes them to blame everyone but themselves for their plight. If this is the case, during the pastoral calling on the prisoner the pastor should help the person to see that spiritual redemption for them waits upon the recognition and confession of their own faults. Making this clear takes courage and repeated visitation, but it must be done if such a situation exists. 23

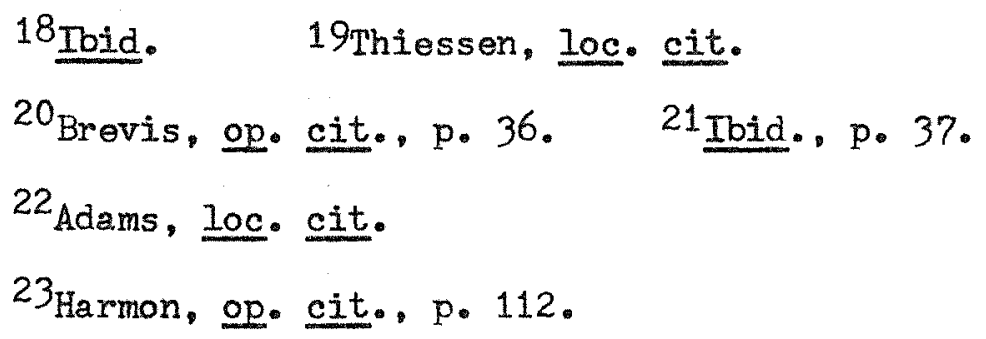


In calling upon those in prison, the pastor must remember to keep faith at all cost, and ". . If a minister makes a pledge of silence, for instance, and under that pledge receives a confession or confidence in question, he must keep his word. . ."24 The only thing he can do is encourage the prisoner to confess himself or allow the pastor to speak for him. 25

Remember helpful suggestions. There are several helpful suggestions listed by George C. Kandle and Henry H. Cassler that could be very valuable to the pastor when he finds it necessary to call on one in prison:

1. Make sure you bring positive identification.

2. Don't plan to give anything directly to the prisoner.

3. Channel Bibles, devotional material, religious medals, etc. through the chaplain. He must set the standards (size, value, appropriateness) for such gifts.

4. Don't send expensive gifts. A two-dollar hardbound Bible is better than a ten-dollar leather-bound Bible. (Some prisoner may steal the ten-dollar Bible to make a watchband with the leather.)

5. Keep your appointments. No single event, except the parole board meeting, excites as much anticipation as a visit.

6. Traveling any distance alone with the prisoner's wife can lead to misunderstanding. It's hard to realize the insecurities prison brings out in a marriage. Try to bring more than one member of the family with you, if possible.26

Continue offering guidance. The pastor can continue offering guidance even after the pastoral call is over by sending letters to the prisoner. The mail has a tremendous influence on the prisoner and is

$$
\begin{aligned}
& 24 \text { Ibid., p. } 113 . \quad 25 \text { Tbid. } \\
& 26 \text { Kandle and Cassler, op. cit., p. } 61 .
\end{aligned}
$$


considered very valuable by him. Visits are more personal, however, less frequent. ". . Mail is the daily bread of a prisoner. .."27 Another way the pastor can continue to offer guidance to the prisoner is by suggesting to aid him in his adjustment period after his release. Kandle and Cassler suggested the following ways the adjustment would be aided by the pastor:

1. Meet him at the prison or the train or bus depot on release. 2. Make specific appointments for him to come to your office: to talk, to drain tension, to discuss problems, to acknowledge fears, and to regard the church as a place of refuge and concern. Suggest four or five meetings the first two weeks. Then meet weekly for a while.

3. Talk with him honestly and openly about ways he can restrain and contain his fears and impulses.

4. Discuss participation in groups with him.

5. Ask for some help from him. Offer him the chance to give to you or the church. He might paint a classroom, fold worship bulletins weekly, or serve on a committee. 28

\section{Possible Results of Pastoral Calling on Those in Prison}

The first possible result the pastor must keep in mind is a negative one. This was suggested by Hampton Adams: "It is almost impossible for a pastor to evade criticism when he offers his friendship to a man who has violated the community's conscience. . .29 However", the pastor might hope for the opposite to result as believed by John Thiessen. He suggested that ealling on those in prison results in an increased respect for the pastor by the community. 30

$$
\begin{aligned}
& 27 \text { Ibid., p. } 63 . \\
& 28 \text { Ibid.. p. } 122 . \\
& 29 \text { Adams, loc. cit. }
\end{aligned}
$$


Another result, which is truly hoped to be achieved, is that the pastor may kindle an interest in the things of the Lord with the prisoner who has never attended church or rekindle that interest in the one who was active in the Lord's work before going astray. 31

III. PASTORAL RESOURCES FOR CALLING ON THOSE WITH SPECIAL NEEDS

Devotional literature and selected Scripture could be of great help to the one who is troubled. Often the written word conveys a message better than any spoken word ever could. The words in the literature, if carefully selected, can continue giving comfort and direction where the pastor left off on his call.

Providing literature for the one in prison, however, is more difficult as it must comply with prison regulations and be channeled through the prison chaplain. Therefore, no literature will be mentioned for them. The pastor must consult the prison chaplain to learn what is best to give. However, the pastor would do well to provide the prisoner with an inexpensive Bible in which he has marked helpful Scriptures. Therefore, Seriptures for the prisoner will be suggested.

Pamphlets to Give to the Troubled

1. Warner Press. Anderson, Indiana. \$.25 each "God's Peace"

"God"s Compassion"

"God's Guidance"

2. Beacon Hill Press. Kansas City. Missouri. \$.25 each

"Now That Trouble Has Come"

31 Ibid. 


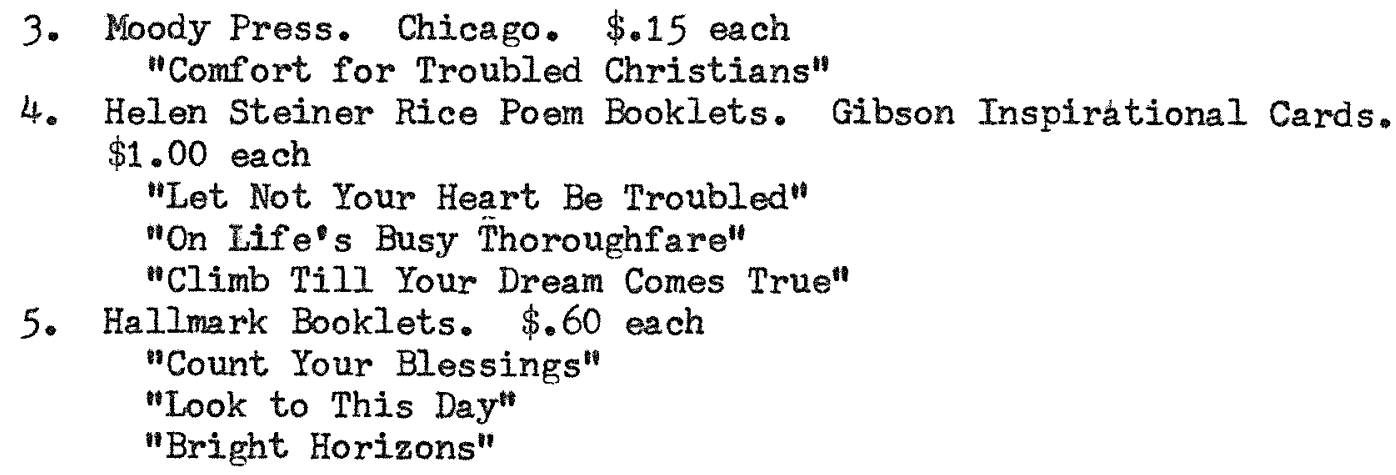

Pooms and Thoughts for the Troubled

"What God Hath Promised"

God hath not promised skies always blue.

Flower-strewn pathways all our lives through;

God hath not promised sun without rain,

Joy without sorrow, peace without pain.

But God hath promised strength for the day,

Rest for the labor. Iight for the way,

Grace for the trials, help from above,

Unfailing sympathy, undying love.

--Annie Johnson Flint

(Taken from James Gilchrist Lawson (ed.). The Best Loved Religious Poems, p. 94.)

\section{"Broken Hopes"}

As the tree is fertilized by its own broken branches and fallen leaves, and grows out of its own decay, so men and nations are bettered and improved by trial, and refined out of broken hopes and blighted expectations.

$-\infty$. W. Robertson

(Taken from Clyde Francis Lytle (ed.), Leaves of Gold, p. 15.)

"Look on the Sunny Side"

There are always two sides, the Good and the Bad, The Dark and the Light, the Sad and the Glad-But in looking back over the Good and the Bad We're aware of the number of Good Things we've had-m And in counting our blessings we find when we're through We've no reason at all to complain or be bluemSo thank God for Good things He has already done, And be grateful to Him for the battles you've won, And know that the same God who helped you before Is ready and willing to help you once more- 
Then with faith in your heart reach out for God's Hand And accept what He sends, though you can't understand-m For Our Father in heaven always knows what is best, And if you trust in His wisdom your life will be blest, For always remember that whatever betide you,

You are never alone for God is beside you. - Helen Steiner Rice

(Taken from an Inspirational Card by Gibson.)

"Never Borrow Sorrow from Tomorrow"

Deal only with the present, never step into tomorrow, For God asks us just to trust Him and to never borrow sorrowFor the future is not ours to know and it may never be. So let us live and give our best and give it lavishly-For to meet tomorrow's troubles before they are even ours Is to anticipate the Saviour and to doubt His all-wise powers-So let us be content to solve our problems one by one, Asking nothing of tomorrow except "Thy Will Be Done."

(Taken from an Inspirational Card by Gibson.)

\section{Scripture Verses (King James Version)}

(The Troubled)

Rom. 5:3 We glory in tribulations also; knowing that tribulation worketh patience.

Psalms 50:15 Call unto me in the day of trouble; I will deliver thee, and thou shalt glorify Me.

Rom. 8:28 We know that all things work together for good to them that love God.

Proverbs 3:5-6 Trust in the Lord with a.11 thine heart; and lean not unto thine own understanding. In all thy ways acknowledge Him, and He shall direct thy paths.

John 14:27 Peace I leave with you, My peace $I$ give unto you; not as the world giveth, give I unto you. Let not your heart be troubled, neither let it be afraid.

Psalms 55:22 Cast thy burden upon the Lord, and he shall sustain thee. Phil. 4:8 Draw nigh to God, and He will draw nigh to you. Prov. 18:24 There is a friend that sticketh closer than a brother. 
(Those in Prison)

John 3:16 God so loved the world that he gave his only begotten Son, that whosoever believeth in Him should not perish, but have everlasting life.

Isaiah 55:6-7 Seek ye the Lord while he may be found, call ye upon Him while $\mathrm{He}$ is near. Let the wicked forsake his way, and the unrighteous man his thoughts; and let him return unto the Lord, and He will have mercy upon him; and to our God, for He will abundantly pardon.

Matt. 16:25 Whosoever will save his life shall lose it; and whosoever will lose his life for My sake will find it.

Phil 4:8 Whatsoever things are true, whatsoever things are honest, whatsoever things are just, whatsoever things are pure, whatsoever things are lovely, whatsoever things are of good report. . think on these things.

I Cor. 10:13 God is faithful, who will not suffer you to be tempted above that ye are able; but will with the temptation also make a way to escape, that ye may be able to bear it.

James 1:12 Blessed is the man that endureth temptation; for when he is tried, he shall receive the crown of life, which the Lord hath promised to them that love Him. 
CHAPTER VI

PASTORAL CAILING ON THE AGED AND SHUT-INS

The aged can be defined as those who due to advanced age are generally restricted to their homes; shut-ins are those who due to illness or physical disability are restricted to their bed, chair, or room in home or hospital. 1 It has been said that it is possible to test a pastor's spiritual depth by inquiring if he calls upon his aged and shut-in persons. These calls truly test the pastor's heart, as the only reward he gains from them is a spiritual one. 2 Consequently, the aged and the shut-ins are the most neglected group in the church, 3 and yet they should not be as their needs must be met just as those of anyone.

Purposes, preparation, procedure, results, and resources are considered in this chapter on pastoral calling on the aged and shut-ins.

I. PURPOSES OF PASTORAL CALLING ON THE AGED AND SHUT-INS

Four purposes of pastoral calling on the aged and shut-ins can be stated. First, the pastor can bring cheer to the aged and shut-ins. 4

1Eugene Dolloff, The Romance of Doorbe11s (Philadelphia: The Judson Press, 1951), pp. 119-20.

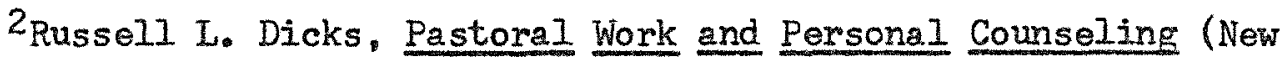
York: The Macmillan Company, 1945), p. 50 .

3Andrew W. Blackwood, Pastoral Work: A Source Book for Ministers (Philadelphia: The Westminster Press, 1945), p. 116.

4 Homer A. Kent, Sr. The Pastor and His Work (Chicago: Moody Press, 1963), p. 269. 
Second, the pastor may help to keep aged persons and shut-ins in contact with the church by developing a relationship and friendship that demonstrates the love of God.5 Third, the pastor needs to bring relief of the feelings of being unneeded and unwanted which are often manifested by the aged and shut-ins.6 Nolan B. Harmon indicated this purpose in reference to the aged. He stated: ". . attention is what old people want. They wish to be noticed; they wish to be made to feel that they still are part of the world."7 Fourth, the pastor must endeavor to alleviate the feeling of loneliness which is so prevalent among the aged and shut-ins. 8 He can help them in this area by leading them to deeper faith and trust in Jesus Christ.

II. PREPARATION FOR CALUING ON THE AGED AND SHUT-INS

In preparing to call on the aged and shut-ins, the pastor must first prepare himself personally, then decide on whom to call and when to call.

5Russell L. Dicks. How to Make Pastoral Calls (St. Louis, Missouri: The Bethany Press, 1962), p. 14.

6Dicks, Pastoral Work and Personal Counseling. p. 50; Dolloff. op. cit., p. 121.

TNolan B. Harmon, Ministerial Ethics and Etiquette (New York: Abingdon-Cokesbury Press, 1928), p. 109.

${ }^{8}$ Dicks, Pastoral Work and Personal Counseling. p. 52. 
Personal Pastoral Preparation

Much of the personal pastoral preparation which was discussed in chapter two and three is applicable to pastoral calling on the aged and shut-ins. Therefore, what was stated in those chapters, is not repeated in this one. The pastor"s personal preparation differs from what was previously stated only in the area of mental preparation. As the pastor ponders his calling on the aged and shuteins, he must think through the needs of these individuals based upon their life before they became aged or shut-in. The aged and shut-ins probably formerly lived busy and useful lives. Suddenly, for the shut-in particularly, these doors were closed. When they reflect on what they might be doing or might have been, it is easy to see why bitterness or a rebellious attitude could occur.9 In preparing mentally to visit the convalescent, the pastor should seek to understand the basic problems facing him. Some of these problems may be: patient's attitude toward his illness; isolation and sensitivity; loneliness; boredom; pain; personality derangements following loss of a limb, or function, or capacity; fear of dependency or economic problem; marital difficulty.10 Therefore, when preparing to call on shut-ins, the pastor must first of all possess the confidence that true miracles do occur in such situations and realize that a strong faith in God brings salvation to

9Dolloff, op. cit., p. 120.

10Richard K. Young, The Pastor's Hospital Ministry (Nashville: Broadman Press, 1954), pp. $\overline{100}-\overline{102}$. 
shut-ins.11 The pastor definitely needs to remember that calls on the aged and shut-ins differ from other calls, as these people require specialized treatment and consideration. 12

\section{On Whom to $\mathrm{CaII}$}

In considering the aged and shut-ins, the pastor must still decide on whom to call. There are ones on the pastor's list of aged and shutains who love to have the pastor come to see them; on the other hand, there are others who are not quite so hospitable. The pastor must be sure that he treats all the shut-in sufferers alike. Showing favoritism in the area of visiting the aged and shut-ins can be destructive to the effective ministry of the pastor. It is easy for the pastor to call on someone who does his soul good, and pass by another who may give him the "shivers."13

\section{When to $\mathrm{CaI1}$}

Because the aged and shut-ins are especially lonely people, they much appreciate the pastor's call. It is easy, however, for them to consume much of the pastor"s time in long conversation. Therefore, it is important not to begin a program of calling on this group that is so strenuous that it cannot be continued. A good suggestion is not to give an exact periodicity to these calls, at first, as they will then

$$
\begin{aligned}
& 11 \text { Ibid., pp. 103-4. 12Dolloff, op. cit.. p. } 123 . \\
& \text { 13Blackwood, 1oc. cit. }
\end{aligned}
$$


always expect it. 14 ". . The size of the parish and the number of shut-ins are qualifying factors, but in any case these visits should be made frequently, monthly if possible. 15

III. PROCEDURE OF PASTORAL CALLING ON THE AGED AND SHUT-INS

As the pastor considers his calling procedure on the aged and shut-ins, he must determine how to direct the call and how to terminate the call.

Directing the Call on the Aged and Shut-Ins

Set tone of the conversation. If the pastor is calling upon the aged, he can expect to hear a great deal about the "good ole" days." It is easy to understand why they would want to recall the busy and exciting years prior to their confined state. As Eugene Dolloff suggested:

- - During the years, few or many, since he shared the ongoing happenings of a oncombusy life, he has been set aside. In many respects. Iife ended for him when he was shut up in home or hospital. Hence, the life which he knows is that which he experienced before he became a shut-in. Happy is the pastor who recognizes this situation and encourages the retelling of those experiences to which the shut in clings so tenaciously. 16

Therefore, when visiting the aged and shut-ins as well, one of the most important things a pastor can do is be a good listener.17 These

14hloyd C. Douglas, The Minister's Everyday Life (New York: Charles Scribner's Son, 1925), pp. 109-10.

15Dolloff, op. cit., p. 126. 16 Ibid., p. 123.

17 Ibid. p. 124 . 
people are hungry for someone who will listen to them.

The pastor can offer sympathy where needed, but he must be careful to make it sympathy that calls for action. The handicapped, particularly, must come to accept and then ignore his deficiency. 18 A Iittle humor, wisely used, can also be used advantageously in the pastor's calling ministry to the aged and shut-ins.19

The nature of the call and conversation should always be a spiritual one $e^{20}$ and employ frequent mention of the church and its activities:

\begin{abstract}
- The majority of the shut-ins reveal an insatiable desire to know in detail about the activities of the church. Of course, one must expect to hear of what 'we did when I was able to go." Encourage the reliving of those blessed experiences, for they always prove a benediction to the shut-in. 21

The aged and the shut-ins also appreciate receiving copies of the Sunday bulletins, keeping them informed of the program of the week and the sermon titles and other items of interest. 22
\end{abstract}

offer guidelines. In directing the call on the aged and shut-ins, the pastor could be doing a great service by carrying on what might be called "occupational therapy." Through what is learned about the

$$
\begin{aligned}
& 18 \text { Young, op. cit. pp. 104-5. 19 Ibid., p. } 105 . \\
& \text { 20 Blackwood, op. cit., p. 117. }{ }^{21} \text { Dolloff, op. cit., p. } 124 . \\
& \text { 22 Lucas Wayne Buttry. The Calling Program of the Local Church } \\
& \text { (Butler, Indiana: The Higley Press, 1956), p. } 26 .
\end{aligned}
$$


person during conversation, the pastor could suggest some quiet outlet for the individual that would occupy his time but still be within his available time and strength.23 with particular regard to the handicapped, Richard Cabot and Russell Dicks, suggested that in addition to offering encouragement to the individual and his family, the pastor should help establish a "ritual of the sickroom." This would involve establishing a plan that would divide up the patient's day into significant and rewarding parts.24 They are as follows:

1. A division of the day into manageable parts; with satisfaction in each and not merely at some remote future time.

2. A daily occupation in which the patient can make progress as long as he sticks to it.

3. An enjoyable climax or a high-point for each day.

4. A family that links beauty and affection to the items of the day's ritual.

5. A chance for the patient to make himself useful.

6. A way to keep in touch with God.25

Cabot and Dicks further suggested particular items which would fall under each of these divisions. 26 Although this suggestion was made particularly for the handicapped, much of it could also be usefully applied to offering guidelines for the aged and other shutmins.

23Young, loc. cit.; Blackwood, op. cit., p. 118.

24 Richard C. Cabot and Russell I. Dicks, The Art of Ministering to the Sick (New York: The Macmillan Company, 1942), pp. $\frac{1}{269-70 .}$

25 Ibid., p. 270.

26 Ibid., pp. $274-75$. 
Terminating the Call on the Aged and Shut-Ins

Ignore time element. When calling upon the aged and shut-ins one must ignore the matter of a specific length of calling time and have a schedule sufficiently flexible to meet unexpected situations. As Eugene Dolloff called to mind:

- - It is to be remembered that time hangs heavily on the hands of practically 2.11 of these friends. For them the hours walk by as if fitted with leaden feet. May we never be so unkind as to call any one of these friends selfish merely because he expects and almost demands an extended call when the pastor comes. 27

Employ singing, Scripture, and prayer. When visiting the aged

and shut-ins, the pastor should consider sharing his faith in an

avenue not previously discussed. This is the avenue of singing. It

cannot be stated any better than it was by Eugene Dolloff:

- - Some pastors when calling upon a shut-in sing one or more of the old hymns. This is a commendable practice to which more pastors might well give themselves. The quality of the singing may not be of the highest order, but it almost unfailingly proves spiritually helpful. If a shut-in friend will be helped, it would seem that nearly any preacher should be willing to assume the risks in thus making "a joyful noise unto the Iord.". . The heart of the pastor will gain a new thrill when he hears his "audience" hum the hymn or actually join with him in the singing of it. More than this, the influence of the song and of the singer will linger in the room and heart of that shut-in person for many days to come. 28

The techniques of the use of Scripture are unique in the area of the aged and shut-ins. Practically all of these people will have favorite passages of Scripture which they would like the pastor to read;

27Dollorf, op. citt., p. 123. 28 Ibid. . p. 126. 
and he should always comply, reading slowly and deliberately. It is also most effective to read from the aged or shut-ins very own Bible. This is very inspirational to the pastor, as well as to the aged or shut-in, as he sees the evidences of the person's long and continual use of the Bible.29

The minister should always pray in connection with these calls:

- The shut-in needs, wants, and expects the pastor to pray. It is manifestly unfair for the minister to ignore this threefold demand. Prayers offered, under the direction of the Holy Spirit, are to be intimate, tender, and personal. All appearance of haste is to be avoided. Words are to be enunciated clearly, distinctly. - Sincerity never goes unrewarded.30

Consider offering communion. The pastor should always serve communion to any aged or shut-in person who requests it. This helps the person to "feel sure that they still belong to the great congregation." 31

IV. POSSIBLE RESULIS OF PASTORAL CALLING ON THE AGED AND SHUT-INS

Pastoral calling on the aged and shut-ins could result in a two-fold outcome. First, it is hoped that as a result of pastoral calling on the aged and shut-ins much of their loneliness and feeling of being unneeded and unwanted will be alleviated. It should certainly be of a great deal of help.

$$
\begin{aligned}
& 29 \text { Ibid. p. 125. } \\
& 31_{\text {Blackwood, op. cit., p. } 118 .}
\end{aligned}
$$


Second, the pastor may find that the aged and shut-ins are doing as much for him and the church as he is doing for them.32 They can offer inspiration to the pastor through words or just through the demonstration of their courageousness in face of trials. 33 They are often ones who have gained a remarkable mastery of the power of prayer, so they can serve as tremendous prayer warriors for the church. 34 It is also very possible that many of the aged and shut-ins can aid the church with their financial support.35

Therefore, calling on the aged and shut-ins will result not only in assistance to them but to the pastor and congregation as well.

V. PASTORAL RESOURCES FOR CALLING ON THE AGED AND SHUT-INS

The pastor will probably make more use of literature with the aged and shut-ins than with any other group on which he calls. These people have a great deal of time with nothing to do, and consequently reading becomes an excellent source of activity. Therefore, the pastor should take quick advantage of this fact and provide or aid in selecting good reading material. In addition to books and pamphlets, the aged and shut-ins would appreciate poems and the use of the Scripture. The

32Theodore L. Cuyler, How to Be a Pastor (New York: The Baker and Taylor Co., 1890), p. 39.

${ }^{33}$ Dolloff, op. cit., pp. $134-35$.

34 Toid. pp. 135-36.

35 Ibid. p. 137. 
reading material need not be short as was the case with the seriously ill, but for the aged it may need to be in large and easy-to-read type. 36

Pastoral References

1. Russell L. Dicks. Comfort Ye My People: A Manual of the Pastoral Ministry. New York: The Macmillan Company, 1947.

2. Russell L. Dicks. Thy Health Shall Spring Forth. New York: The Macmillan Company, 1946.

3. William A. Lauterbach. Ministering to the Sick. St. Louis, Missouri: Concordia Publishing House, 1955.

Pamphlets to Give to the Aged and Shut-Ins

1. Warner Press. Anderson, Indiana. \$.25 each "God at My Bedside" by Eugene L. Mendenhall, Jr. "Faith"

"God"s Sufficiency"

"God "s Gifts"

"God's Compassion"

2. Beacon Hill Press. Kansas City, Missouri. \$.25 each

"You Can Be a Happy Shut-In" by Kathryn Blackburn Peck

3. Helen Steiner Rice Poem Booklets. Gibson Inspirational Cards. $\$ 1.00$ each

"Prayers and Meditations"

"Just for You"

4. Hallmark Booklets. $\$ .60$ each

"Songs of the Season"

"Meditations by Peter Marshalz"

"The Beauty of Sounds"

"Look to This Day"

\section{Poems and Thoughts}

"A Prayer for Older People"

Father, Thou knowest I am growing older. Keep me from becoming talkative and possessed with the idea that I must express myself on every subject. Release me from the craving to straighten out everyone's affairs. Keep my mind free from the recital of endless

36 William A. Lauterbach. Ministering to the Sick (St. Louis, Missouri: Concordia Publishing House, 1955), pp. 23-24. 
detail. Seal my lips when I am inclined to tell of my aches and pains. Teach me the glorious lesson that occasionally I may be wrong. Make me thoughtful but not moody, helpful but not bossy. With my vast store of wisdom and experience, it seems a pity not to use it all, but Thou knowest, Lord, that I want to keep my friends until the end. Amen.

(Taken from a special publication from Guideposts.)

"Look on the Sunny Side"

There are always two sides, the Good and the Bad, The Dark and the Light, the Sad and the Glad-o. But in looking beck over the Good and the Bad We 're aware of the number of Good Things we ve had-m And in counting our blessings we find when we re through We"ve no reason at all to complain or be blue-w So thank God for Good things He has already done, And be grateful to Him for the battles you've won, And know that the same God who helped you before Is ready and willing to help you once moremThen with faith in your heart reach out for God's Hand And accept what $\mathrm{He}$ sends, though you can't understand-For Our Father in heaven always knows what is best, And if you trust in His wisdom your life will be blest. For always remember that whatever betide you, You are never alone for God is beside you.

(Taken from an Inspirational Card by Gibson.) - Helen Steiner Rice

"Perspective"

To be seventy years young is sometimes far more cheorful and hopeful than to be forty years old.

(Taken from Clyde Francis Lytle (ed.). Leaves of Gold. p. 20.)

"There Is Not a Friend Like Jesus"

There is not a friend like Jesus in the trying scenes of life;

He can hear the heart's faint whisper, calm the tempest's raging strife.

There is not a friend like Jesus, patient, tender, kind and true:

If you'll be a friend of Jesus, He will be a friend to you. - Mrs. H. A. Hendricks

(Taken from Hymnal of the Church of God. Anderson, Indiana, p. 335.) 


\section{Scripture Verses (King James Version)}

II Cor. 4:16-17 For which cause we faint not; but though our outward man perish, yet the inward man is renewed day by day. For our light affiction, which is but for a moment, worketh for us a far more exceeding and eternal weight of glory.

II Cor. 5:? For we walk by faith, not by sight.

II Cor. 12:8,9 For this thing I besought the Lord thrice that it might depart from me. And He said unto me, My grace is sufficient for thee; for my strength is made perfect in weakness.

Psalms 40:1 I waited patiently for the Lord; and He inclined unto me and heard my cry.

Isaiah 26:3 Thou wilt keep him in perfect peace whose mind is stayed on Thee; because he trusteth in Thee.

Lam. 3:31-33 The Lord will not cast off forever; but though He cause grief. yet will He have compassion according to the multitude of His mercies: For He doth not afflict willingly nor grieve the children of men.

Psalms 71:18 Now also when I am old and grayheaded, 0 God, forsake me not; until I have showed Thy strength unto this generation and Thy power to everyone that is to come.

Psalms 73:26 My flesh and my heart faileth; but God is the strength of my heart and my portion forever. 


\section{CHAPTER VII}

\section{PASTORAI CALIING ON PROSPECTIVE MEMBERS}

Pastoral calling on prospective members takes in three groups of peoplemenewcomers to the church, newcomers to the community, and the unevangelized. Each of these three cases will be handled individually with a discussion on unique considerations the pastor must keep in mind when making such a call. General information on calling on prospective members can be obtained in chapter two.

\section{NEWCOMERS TO THE CHURCH}

When a new family visits the church, and especially if there are children for the church school, the pastor should call immediately in the name of the church.1 After introducing himself, letting them know of his pleasure in having them visit the church, and having a friendly visit, the pastor will give them names of one or two families from the church who live nearby. He will then ". . tell the neighbors about the new people and let the Christian community work. . . 2

1 Robert N. Rodenmayer, We Have This Ministry (New York: Harper and Brothers Publishers, 1959), p. 40.

2Tbid.; of. James Albert Beebe, The Pastoral Office (New York: The Methodist Book Concern, 1923), p. 287. 


\section{NEWCOMERS TO THE COMMUNITY}

It has sometimes been said that a large city can be a very lonely place for one who has come from the country or small town. But the country or small town can also be very lonely for one who grew up in the city. In most cases these lonely people are strangers who have just come into the community. The pastor should make it his business to find such strangers, make them welcome, invite them to church, and see if there is any service he can perform for them... 3

The wise pastor keeps his eyes open for new people who move into the community and keeps in mind that the best time to win a new family comes at once."4 The pastor should wait a couple of days while the family gets the household basically in order before he calls. During this time, however, the women of the community can show the newcomers the sort of attention strangers like." . . At first they do not need callers as much as neighbors. . W5 When the pastor does call, he should show the newcomers the loving kindness of the Lord.

- - Tactrully he learns what he should know about the various members of the household, including those away from home. He also Iinds out which parts of the church program appeal to the various nembers of the household. . . 6

With this sort of care, newcomers to the community should not only lose their feelings of loneliness knowing they have new friends but they should feel welcome to worship in the nearby congregation.

3John Caldwell Thiessen, Pastoring the Smaller Church (Grand Rapids: Zondervan Publishing House, 1962), p. 92.

4Andrew Watterson Blackwood, Pastoral Work: A Source Book for Ministers (Philadelphia: The Westminster Press, 1945), p. 151.

5Ibid.. p. 154; cf. Thiessen, 1oc. eit.

6Blackwood, loc. cit. 
III. THE UNEVANGELIZED

The unevangelized also have a claim upon the pastor's calling time. This group includes not only the unchurched but the unconverted as well.". . and all who have never ventured into the deep places of Christian experience, whether members of the church or not...."? The names of these people compose what the pastor might call his "Personal Work List," which only he and God see.

- These must be cultivated persistently and lovingly, though with tact and common sense. There should be no nagging, yet there must be constant pursuit which never abandons the holy chase. Let the pastor angle for these souls as the fisherman angles for the wary trout. He should be tactful, yet at times be ready to risk a blunder by bold adventuring. This work must go on month after month, intensified, perhaps, during special meetings, but not abandoned when meetings are done. 8

\section{PASTORAL RESOURCES FOR CALLING ON PROSPECTIVE MEMBERS}

When calling on newcomers to the church and newcomers to the community, few actual resources will be needed as the call is mainly one to let newcomers know the pastor is interested in them. The pastor"s main resources will come from the abundance of a loving heart as he seeks to show these newcomers that God and the church care about them. When visiting newcomers, however, a personalized church "Welcome Packet" would be a beneficial resource. A short prayer might be given if the situation so lends it, particularly for newcomers to the church.

\footnotetext{
7Beebe, op. cit., p. 289.

${ }^{8}$ Ibid. . p. 290 .
} 
However, calling on the unevangelized would require greater use of

pastoral resources.

Pamphlets to Give to Prospective Members

(For newcomers to church and community)

1. Personalized church welcome packet

(For unevangelized)

2. "Four Spiritual Iaws" Campus Crusades for Christ

3. "Life Eternally Yours"

Stonecraft Book and Supply Center. Kansas City. \$.25 each

\section{Scripture Verses for the Unevangelized (King James Version)}

John 3:16 For God so loved the world, that He gave His only begotten Son, that whosoever believeth in Him should not perish, but have everlasting life.

John 10:10 I am come that they might have life, and that they might have it more abundantly.

Romans 3:23 For all have sinned and come short of the glory of God.

Romans 6:23 For the wages of $\sin$ is death; but the gift of God is eternal life through Jesus Christ our Lord.

Romans 5:8 But God proves His love for us, in that while we were yet sinners, Christ died for us.

John 14:6 Jesus saith unto him. I am the way, the truth, and the life: no man cometh unto the Father, but by me.

John 1:12 But as many as received Him, to them gave He power to become the sons of Cod, even to them that believe in His name.

Rev. 3:20 Behold I stand at the door and knock: If any man hear my roice, and open the door. I will come in to him... 


\section{CHAPTER VIII}

\section{PASTORAL CALIING ON EACH FAMIIY}

"No one has a right to regard himself as a good shepherd who does not plan to visit personally every family at least once a year."1 This is a strong and forceful statement but one that conveys well the great importance of pastoral calling on each church family. Although this may prove impossible to accomplish alone in a large congregation, the pastor needs to make an honest attempt. The pastor is peculiarly a pastor of families, not just individuals; and he must remember that the strength of Christianity is not found in the church, but in the home. 2

This type of calling might also be termed the routine call as it is systematically calling on each church family regardless of their spiritual needs and without specific purpose in the way of church organizational promotion. Because the pastor calls by his own choice and not due to a particular need, it is one of the most effective and appreciated ealls.3 This type of calling will again be considered under the divisions of purposes, preparation, procedure, possible results, and pastoral resources.

1 James Albert Beebe, The Pastoral Office (New York: The Methodist Book Concern, 1923), p. 278.

2 Peter H. Pleune, Some to Be Pastors (New York: Abingdon-Cokesbury Press, 1943), p. 50 .

${ }^{3}$ Russell L. Dicks, Pastoral Work and Personal Counseling (New York: The Macmillan Company, 1945), p. 60 . 


\section{PURPOSES OF PASTIORAL CAIJING ON EACH FAMILY}

The first purpose of pastoral calling on each family is to get to know the families and establish friendly relations between the pastor and every member of every family. By establishing such a relationship during the routine call, the pastor is able to be useful when times of emergency arrive. 4 "The pastor must go to the people through routine calling if they are to come to him in time of difficulty." 5

A second purpose is that the pastoral call on each family gives an opportunity to widen the horizon of the ones he goes to see:

- - Of course, the pastor is chiefly desirous of introducing people to God and a deepening relationship with Him. That leads to the widest horizons of a.ll, and is the objective which gives meaning to everything else. But, rightly understood, every fresh and worthy interest should be regarded as contributing to that end. We must begin with people where they are; and that means beginning with each one in a different place. . . 6

In making the routine call, another purpose is to discover anyone who may need special help--troubled, disaffected, or indifferent-and aid them as much as possible.? By discovering spiritual or emotional needs in an early stage, they can be corrected before they become serious problems. 8

${ }^{4}$ Beebe, op. cit., p. 279; Paul Rowntree Clifford, The Pastoral Calling (New York: Channel Press, 1961), pp. 75-76.

5Dicks, op. cit., p. 28. ${ }^{6}$ Clifford, op. cit. pp. 78-79.

7Beebe, op. cit., p. 280 .

8 Dicks, op. cit. p. 60 . 
A fourth calling purpose, as suggested by James Beebe, is that this kind of calling binds the church constituency into a single spiritual unity. 9 Preparing the ground and opening the way for the counseling situation is a fifth purpose of pastoral calling on each family. 10

The sixth and final purpose might seen superficial but it can be very important to the pastor and his record system. Routine calling helps the pastor keep his map of locality 11 up to date and enables him to continually re-survey the community noting new facts and faces, and changes of residence. 12

Having considered these six purposes of pastoral calling on each family, the pastor should see the importance of this phase of calling:

- - here is an art that demands the best gifts of heart and mind, a God-given concern for people and a sanctified imagination. There is much that can be leamed by way of technique, . . But in the last resort the key to success or failure lies in a man's clear definition of his objectives and the devotion with which he sets out to attain them. 13

\section{PREPARATION FOR PASTORAL CALLING ON EACH FAMILY}

The pastor must decide on whom to call and when to call before actually setting out to call on the church families.

9 Beobe, loc. cit. $\quad 10 \mathrm{Clifford}$ op. cit. p. 79.

${ }^{11}$ See chapter two, page 37.

12 Beebe, loc. cit. 13clifford, op. cit., p. 80. 
On Whom to Call

Show no partiality. When calling upon families, the pastor must be careful to take a good account of his attitude and make sure he does not show partiality to some families in his congregation.14 This means he will call on all alikempeople of various occupations, different states of health, varying cultural levels, in neat and orderly kept homes and those just the opposite. ".. He no doubt will find places that he prefers, but he should practice impartiality. . .15

Plan calls systematically. It is when the pastor begins to lay plans for making calls on each family that his pastoral records, as discussed in chapter two, are particularly valuable. If he has calls to make on the sick or bereaved on the same day, he should select homes to visit within the same area where he will be making these calls. The number he plans to make will vary according to the time he has available and to the length of each call. It is better to plan for more calls than one expects to accomplish.16 After selecting the part or parts of the community where the pastor will call, he should go to his map of locality 17 and write down the names of the families in that area.

14 Peter Y. DeJong, Taking Heed to the Flock (Grand Rapids: Baker Book House, 1948), p. 72 .

15John Caldwell Thiessen, Pastoring the Smaller Church (Grand Rapids: Zondervan Publishing House, 1962), p. 94.

16 Eugene Dinsmore Dolloff, The Romance of Doorbells (Philadelphia: The Judson Press, 1951), p. 66.

17 See chapter two, page 37. 
Then he goes to his family card file. 18 From this file he seeks to gain knowledge of the size and nature of the family. He should know who the members of the family are, when they were last visited, and take special note of any family member who has a responsibility in the church. It is important to know and remember the name of each family member.19 The pastor should also make special note of a household having a new baby.

When to $\mathrm{CaII}$

Discussions on the time of day to call and deciding whether to call by appointment or unexpectedly were thoroughly handled in chapter two and therefore do not need to be repeated completely again. 20 In summary it can be said that calls made on the family should be done in the early afternoon or evening. An evening call might be necessary in order to get to call on the husband as well as the mother and children. An alternative would be to call on the man at his place of business keeping in mind not to call too often or stay too long. 21 However, the call in the evening would be preferred. Some feel it is best to call ahead for an appointment whereas others say go completely unannounced. 22

18 See chapter two, page 38.

19 John Charles Wynn, Pastoral Ministry to Families (Philadelphia: The Westminster Press, 1957), p. 53.

20 See chapter two, pages $24-27$.

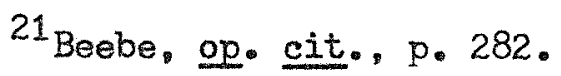

22 Wynn, 1oc. cit.; Beebe, op. cit., p. 283. 
A "middle of the road" suggestion is to inform the congregation. through the bulletin or by announcement, the locality where the pastor will call that week. 23 The size of the congregation will determine how frequently the pastor can call on each family, but generally he should strive for the goal of at least one call per family per year. 24

\section{PROCEDURE OF PASTORAL CALLING ON EACH FAMILY}

In order to cover the subject adequately on the procedure of pastoral calling on each family, the material is considered under two headings: directing the call on each family and terminating the call on each family.

Directing the Call on Each Family

In directing the pastoral call on each family, the pastor must remember that it is not to be merely a social call but one that is spiritual in nature exereising oversight in the name of Christ.25 It is for this roason John wynn advocated calling ahoad for an appointment:

- Pastors who follow this practice report that the entire family manages to be present, and that it opens the way to speak of more essential items than the weather, to talk of the minister"s role, and the church fellowship....26

23Thiessen, 1oc. cit.

24 Ibid.: Ambrose Moody Bailey, The Pastor in Action (New York: Round Table Press. Inc., 1939), p. 174 .

25 DeJong, op. cit., p. 73.

26 Wynn, 10c. cit. 
James Beobe suggested the pastor carry a spirit of buoyant faith and hearty cheer into each home he visits. ". A sanctified inagination (common sense) will suggest the particular things which should be done. - ."27 This tends to vary with the pastor's personality as well as the home conditions. 28

During the course of the call the pastor might discuss such matters as the importance of the Christian family. He will also take special note of one who is a worker in the church, encouraging and showing him appreciation. Listening, as well as talking, is an important part of the call.29 These calls on the family need not be long, and would be best kept brief. 30

Calling upon mothers with new babies is also a part of the family ministry that ought never to be forgotten.

- Mothers at this time may feel the presence of cod in a new way that they have never known before. A father may be filled with a gladness that the dispensing of cigars can never express. The birth of a child in the parish is a time for rejoicing as well as for instruction. 31

The pastor can take advantage of this special time to draw closer to the family letting them know the church is happy for them and offering them Christian guidance as they enter into this now adventure.

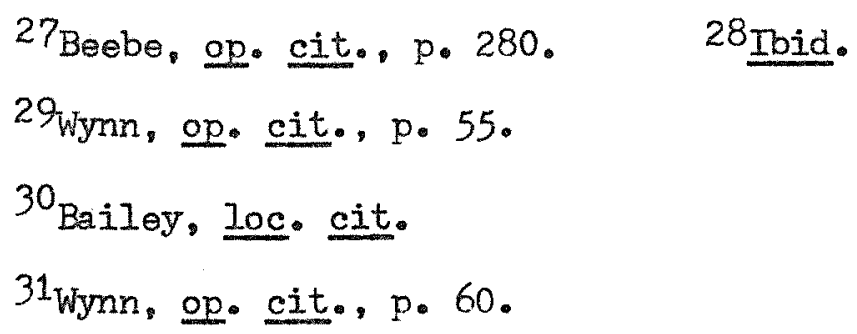


Terminating the Call on Each Family

Terminating any pastoral call with Scripture and prayer is never a necessity. However, if the situation lends itself in that direction at 211 , the pastor is wise in carefully making use of these Christian tools. If the pastor directs the conversation gradually along from merely social to spiritual talk, a brief scripture reading and agreement in a family prayer would follow naturally and be an excellent method of terminating the call. In deciding what to do as a pastor, James Beebe stated it well: ". . Let him be as wise as the healer of the body, who makes a careful diagnosis of each case and adapts the treatment to the disease." 32

IV. POSSIBIE RESULTS OF PASTORAI CALLING ON EACH FAMTIY

It is hoped that many helpful results will occur due to the pastor's determined effort to call systematically each year on every church family. First, the pastor gains several results due to this type of calling. He comes to know each family and its members and their spiritual condition. 33 He is made aware of any problems that may be arising and can aid in correcting them early in their development. 34 It enables the pastor to demonstrate a spirit of Christian love and helpfulness.35 Finally, by visiting all areas of his church community

$$
\begin{aligned}
& 32 \text { Beebe, op. cit., pp. } 281-82 . \quad 33 \text { DeJong, op. cit., p. } 65 . \\
& 34 \text { Ibid., p. } 66 . \\
& 35 \text { Ibid., p. } 67 .
\end{aligned}
$$


at least once a year, he keeps current on changes in the community. 36

Secondly, there are positive results for the parishioners when the pastor makes calls on each church family. They come to know their pastor and gain confidence in him.37 It provides a unity of the parishioners. 38 Also, they come to know the value of discussing spiritual matters, are aided in striving to live more consistent Christian lives, and learn the high ideal of living together as a Christian family from day to day. 39

V. PASTORAL RESOURCES FOR CALIING ON EACH FAMIIIY

When making routine calls on each church family, suggestions for pastoral resources could be helpful. The pastor might share a poem or thought with the family and read or quote a passage from the Bible. He might also leave a pamphlet or booklet of inspiration in the home.

Pamphlets to Give to Each Family

1. Beacon Hill Press. Kansas City, Missouri. \$.25 each

"You Need a Family Altar" by Joseph Gray

"Now That You"re Parents" by Earl C. Wolf

2. Hallmerk Booklets. \$.60 each "God's Masterpiece"

"Bless This House"

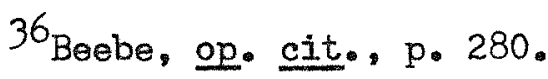

37 DeJong, op. cit. p. 69.

38 Ibid. p. 67.

39 Ibid. pp. 68-70. 
Poems and Thoughts

"Happy the Home When God is There"

Happy the home when God is there, and love fills every breast;

When one their wish, and one their prayer,

And one their heavenly rest.

Happy the home where Jesus' name is sweet to every ear;

Where children early lisp his fame,

And parents hold him dear.

Happy the home where prayer is heard, and praise is wont to rise:

Where parents love the sacred word,

And live but for the skies.

Lord let us in our homes agree this blessed home to gain;

Unite our hearts in love to thee,

And love to all will reign.

- -Henry Ware

(Taken from Hymal of the Church of God, Anderson, Indiana, p. 454.)

"The Art of Marriage"

A good marriage must be created. In the art of marriage the little things are the big things...

It is never being too old to hold hands.

It is remembering to say, "I love you," at least once each day.

It is never going to sleep angry.

It is having a mutual sense of values and common objectives; it is standing together facing the world.

It is forming a circle of love that gathers in the whole family.

It is speaking words of appreciation and demonstrating gratitude in thoughtrul ways.

It is having the capacity to forgive and forget.

It is giving each other an atmosphere in which each can grow.

It is finding room for the things of the spirit.

It is a common search for the good and the beautiful.

It is not only marrying the right partner, it is being the right partner.

-milferd A. Peterson

(Taken from Arthur and Nancy Delfoss (eds.). The Gold Star Family Album, p. 52 . 


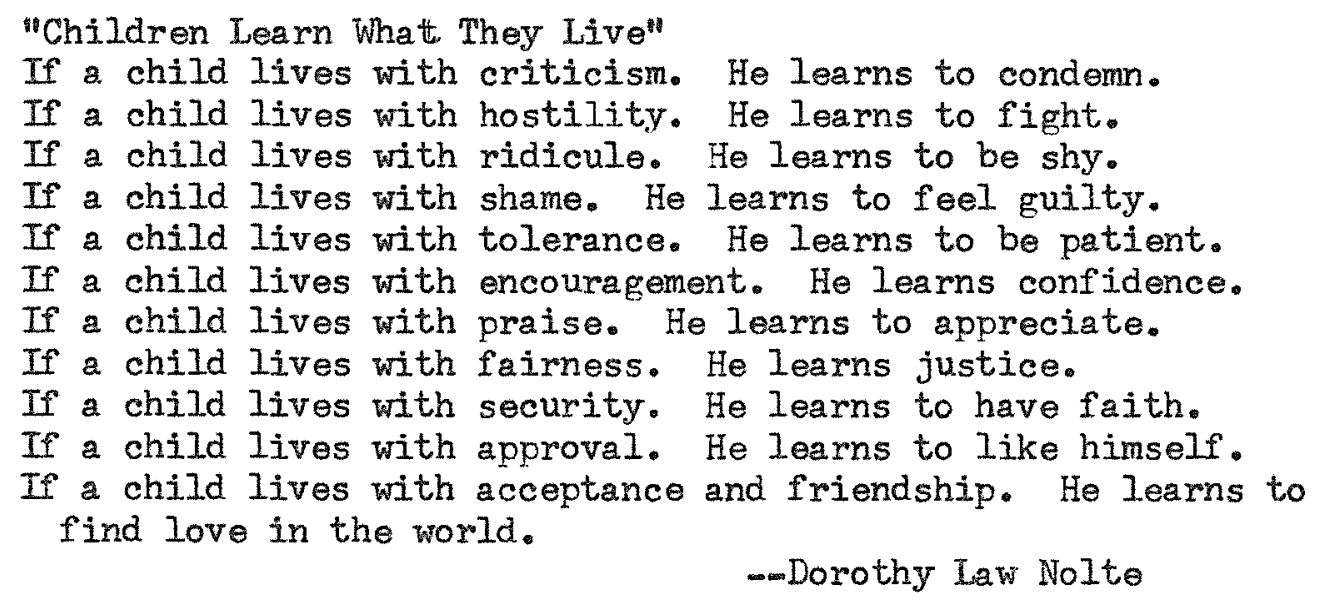

"What Is a Baby?"

A wee bit of heaven drifted down from above, A handful of happiness, a heartful of love-Wonder of wonders, so soft, sweet and small. Without which there'd be just no life at alll

A baby is a gift of Iife born of "the wonder of love," A little bit of eternity sent from the Father above. Giving a new dimension to the love between husband and wife And putting an added meaning to the wonder and mystery of lifel - Helen Steiner Rice

(Taken from an Inspirational Card by Gibson.)

\section{Scripture Verses (King James Version)}

Psalms 127:1 Except the Lord build the house, they labour in vain that build it.

Joshua 24:15 But as for me and my house, we will serve the Lord. Col. $3: 2$ Set your affection on things above, not on things on the earth.

Psalms 92:1 It is a good thing to give thanks unto the lord, and to sing praises unto Thy name, 0 Most High.

Psalms 127:3 Lo, children are an heritage of the Lord, and the fruit of the womb is His reward.

Prov. 22:16 Train up a child in the way he should go, and when he is old, he will not depart from it. 
CHAPTER IX

SUMMARY AND CONCLUSION

For an effective pastoral calling program the pastor needs to know general guidelines of pastoral calling. Pastoral calling must be purposive. General purposes of pastoral calling include: (1) pastor comes to know his people, (2) people come to know their pastor, (3) pastoral calling implements preaching with vital homiletical material, (4) pastoral calling strengthens church finances, (5) pastoral calling meets evangelistic opportunities, (6) pastoral calling stimulates church attendance, (7) pastoral calling affords counseling opportunities, and (8) in pastorel calling the pastor represents Christ and the church. Specific purposes include: (1) to comfort and encourage the sick, (2) to console and strengthen the bereaved, (3) to give direction and spiritual guidance to the troubled and to those in prison. (4) to bring cheer and a sense of worth to the aged and shut-ins, (5) to welcome newcomers to the church and community. (6) to share the gospel with the unevangelized, and (7) to show an interest in and encourage the church families.

Preparation is necessary for an effective program of pastoral calling. The pastor must be personally prepared: spiritually, mentally, and physically. The pastor must know on whom to call. He calls according to the urgency of the need; he shows no partiality; he plans his calls systematically. The pastor must decide when to call. He must find time to call; he must determine the time of day to call; he 
must decide whether or not to call unexpectedly or by appointment.

In making pastoral calls the pastor needs to realize the significance of calling procedure. As the pastor enters the home, he must follow rules of common courtesy and keep his calling purpose in mind. In directing the conversation during the call, the pastor needs to set the tone of the conversation, be a good listener, and avoid certain situations and topics of discussion. The pastor must determine the length of his calls. He also needs to be adept at terminating the pastoral call.

The results of pastoral calling are important to the pastor. His own life may be enriched; his ministry is kept down to earth. He is able to preach and pray more sympathetically. The church attendance may increase. The pastor gains the confidence of his people. The door may be opened for personal counseling.

For the pastor to maintain an effective pastoral calling ministry. he needs to have an adequate system of records. A locality map is a helpful tool and record for the pastor's calling program. The pastor can keep track of his daily calls by using a daily calling ledger. The family card file can help the pastor to keep his family calling up to date. The individual card file, which is for pastoral use only, is a valuable aid to the pastor's calling ministry. The pastor may help his parishioners to understand better his program by presenting a monthly report of his pastoral calling activities.

One of the most urgent tasks of the pastoral ministry is calling on the sick. The purposes of calling on the sick are: (1) to comfort 
and encourage the sick one, (2) to comfort the family of the sick one, (3) to exercise the ministry of physical healing, and (4) to help the sick one grow spiritually.

Preparation is essential to effective pastoral calling on the sick. The pastor must prepare himself spiritually, mentally, and physically before beginning to call on the sick. The pastor needs to know on whom to call. He should train his people to tell him of sick ones; he must minister closely to some needing special attention; yet, he dare not show partiality. The pastor must know when to call. He should call promptly; he must determine calling frequency; he needs to be considerate of visiting hours.

The procedure of pastoral calling on the sick is important. When entering the sickroom, the pastor must be careful in his approach and size up the situation. In directing the sickroom call, the pastor must set the tone of the conversation and keep certain facts in mind. In terminating the sickroom call the pastor should remember to keep the call brief, incorporate Scripture and prayer wisely, and consider offering communion. The pastor must give special consideration to the pre-surgical case, the unconscious, the one with a communicable disease, the dying, the sick or injured child, and the mentally 111 .

The results of pastoral calling on the sick may be the fulfillment of the purposes. The faithful may be strengthened; the careless may be returned to faithfulness; the unsaved may be reached; the pastor may develop a more sympathetic nature.

Pastoral resources for calling on the sick may include: reference books for the pastor, pamphlets to give to the patient, thoughts and 
poems, and Scripture verses to be used.

Pastoral calling on the bereaved is a very important phase of the pastor"s calling ministry. The purposes for calling on the bereaved are: (1) to comfort and console the bereaved in his time of grief, and (2) to offer him strength through Jesus Christ.

Preparation is important to the effectiveness of calling on the bereaved. The pastor must make personal preparation before calling on the bereaved. He needs to know when to eall, which is generally immediately upon hearing the news of a death.

The procedure of calling on the bereaved is extremely important to the pastor; for the effectiveness of the call depends upon what he does during the call. In directing the call on the bereaved, the pastor must be considerate and needs to help the bereaved through stages of grief. The pastor should terminate the call with prayer; helpful Scripture may be quoted by the pastor. The pastor must continue to call upon the bereaved after the funeral.

The possible results of pastoral calling on the bereaved include: the bereaved passing through all the stages of bereavement successfully by spiritual guidance, and new souls being added to the kingdom of Cod.

It is helpiul for the pastor to have special resource materials for his calling on the bereaved. These resources may include: pamphlets to give to the bereaved, poems and thoughts, and scripture verses to be used.

Calling on those with special needs is an important phase of the pastoral calling ministry. The pastor must give attention to those who are troubled by loneliness, by discouragement, by dissatisfaction, or by 
a deep spiritual need.

The pastor must not neglect those, connected in some way to his parish, who are in prison. In calling on the prisoner the pastor should purpose in his heart to show the prisoner a better way and to help the prisoner stabilize himself by tapping his ow spiritual resources. In preparing to call on a prisoner, the pastor should avail himself to the rules and regulations of prison visitation. The procedure of calling on those in prison is important. The pastor must set the tone of the conversation; he should continue to offer guidance through correspondence. The possible results of calling on those in prison are: (1) may cause others in the community to be critical of the pastor, (2) may result in increased respect for the pastor, and (3) may help the prisoner to turn to the Lord and rekindle family interest in spiritual things. Pastoral resources for those with special needs include: pamphlets to be given to the troubled, poems and thoughts, and scripture verses to be used.

The importance of pastoral calling on the aged and shut-ins dare not be overlooked. The purposes of pastoral calling on the aged and shut-ins are: (1) to bring cheer, (2) to help them keep in contact with the church, (3) to bring relief of the feelings of being unneeded and unwanted, and (4) to alleviate feelings of loneliness and draw them closer to God.

The pastor must make preparation for calling on the aged and shut-ins. He should prepare himself spiritually, mentally, and physically for this important ministry; he needs to know on whom to call, being 
careful not to show partiality; he must decide when to call and how often to call.

It is important for the pastor to know what to do when he calls on the aged and shut-ins. In directing the call on these people, the pastor needs to set the tone of the conversation; he also should offer guidelines to help the person to a more fruitrul life. In terminating the call on the aged and shut-ins, the pastor generally ought to ignore the time element; he should read Scripture and pray and, if possible, even sing; he also should consider offering communion. Possible results of pastoral calling on the aged and shut-ins include: alleviation of their loneliness and feelings of being unneeded and unwanted, strengthened spiritual life, and inspiration to the pastor from the dedication and prayer life of some of the aged and shut-ins. Pastoral resources for calling on the aged and shut-ins include: reference books, pamphlets to give to the aged and shut-ins, poems and thoughts, and Seripture verses to be used.

The pastor has the important task of calling on prospective members. The pastor should call on the newcomers to the church. expressing to them of his pleasure in having them visit the church. Calling on newcomers to the community is a good practice for the pastor to establish. New members may be added to the church and to the kingdom of God by the faithful practice of pastoral calling on neweomers to the church and community.

The pastor also has the responsibility of calling on the unevangelized. The unchurched and unconverted should have the "good 
news" of Jesus Christ shared with them by the pastor.

Pastoral resources include pamphlets to give to prospective members and Scripture verses the pastor might share with the unevangelized. The spirit of the pastor himself is the main resource when ealling on newcomers to the church and community.

The final group on whom the pastor calls is each church family. This may be one of the most effective and appreciated calls, because the pastor calls by his own choice and not due to a particular need. There are six purposes for this type of call: (1) to get to know each family and establish friendly relations, (2) to widen the horizon of each family, (3) to discover anyone needing special help. (4) to create a spiritual unity among the church constituency, (5) to prepare the ground for a counseling situation, and (6) to keep up to date with the changing community.

In preparing to call on each family, the pastor must decide on whom to call, showing no partiality and planning the calls systematically. He must also consider when the best time would be to call to find the whole family home.

As the pastor actually calls on the family, he must remember that his call is to be of a spiritual nature. The particular things which should be done vary with each pastor, but he should encourage the family and show special appreciation to those who are workers in the church. The pastor should take advantage of offering Christian guidance to those homes with a new baby. The call may be teminated with Scripture and a prayer if the situation lends itself that way. 
As a result of calling on each family the pastor comes to know his people, special problems are corrected early, Christian love is demonstrated, and community changes are noted. The parishioners also benefit as they gain confidence in the pastor, become unified with fellow parishioners, are aided in their attempt to live a consistent Christian life, and learn the importance of the Christian family. Helpful pastoral resources when calling on each family are: pamphlets, poems and thoughts, and Scripture verses.

Pastoral calling must never be regarded as a vanishing tradition and an intolerable task. It is a very vital phase of the pastoral ministry that deserves careful consideration and attention by every pastor of a congregation. This fact should be clearly understood through the positive and careful presentation of the material on general calling guidelines, pastoral calling on the sick, pastoral calling on the bereaved, pastoral calling on those with special needs, pastoral calling on the aged and shut-ins, pastoral calling on prospective members, and pastoral calling on each family. In the words of Peter H. Pleune:

The one thing imperative is that we give ourselves conscientiously and devotedly to this phase of our ministry. We cannot read the gospel story of him who "came not to be ministered unto, but to minister. without being impressed with his personal relationships. He touched all sorts of people. He was always giving himself to others. We read that he called the Twelve that they should be with him. Their personal relationship with him was a part of their training and of their final commitment of themselves to him. The Twelve were often surprised at his wayside ministries. He was never too busy to meet people and to do something for them. Nothing was an interruption for him, and some of the greatest things he did were done on the way to doing something else. No service and no demand were ever to him a routine or a burden. Jesus loved people. 
As his minister we must know people and love them too. Some of the ways to do it may often seem prosaic. And one of the ways is the ringing of doorbells. But if wo do it faithfully and well, there will be an answering response in the hearts of men. And that is what calling is for. 1

${ }^{1}$ Peter H. Pleune, Some to Be Pastors (New York: AbingdonCokesbury Press, 1943), pp. 58-59. 
BIBLIOGRAPHY 


\section{BIBLIOGRAPHY}

\section{A. BOOKS}

Adans, Hampton. The Pastoral Ministry. New York: Cokesbury Press, 1932.

Babbitt, Edmond Holt. The Pastor's Pocket Manual for Hospital and Sickroom. New York: Abingdon-Cokesbury Press, 1949.

Bailey, Ambrose Moody. The Pastor in Action. New York: Round Table Press, Inc., 1939.

Becker, Russell J. Family Pastoral Care. Paperback Edition. Philadelphia: Fortress Press, 1968.

Beebe, James Albert. The Pastoral Office. New York: The Methodist Book Concern, 1923.

Belgum, David. Clinical Training for Pastoral Care. Philadelphia: The Westminster Press, 1956.

Blackwood, Andrew Watterson. Pastoral Work: A Source Book for Ministers. Philadelphia: The Westminster Press, 1945.

Brister, C. W. Pastoral Care in the Church. New York: Harper and Row, Publishers, 1964.

Buttry, Lucas Wayne. The Calling Program of the Local Church. Butler, Indiana: The Higley Press, 1956.

Cabot, Richard C. and Russell I. Dicks. The Art of Ministering to the Sick. New York: The Macmillan Company, 1942.

Calkins, Raymond. The Romance of the Ministry. Boston: The Pilgrim Press, 1944.

Clifford, Paul Rowntree. The Pastoral Calling. New York: Channel Press, 1961.

Cuyler, Theodore L. How to Be a Pastor. New York: The Baker and Taylor Company, 1890.

DeJong, Peter Y. Taking Heed to the Flock. Grand Rapids: Baker Book House, 1948.

DeMoss, Arthur and Nancy (eds.). The Gold Star Family Album. Westwood. New Jersey: Fleming H. Revell Company, 1966. 
Dicks. Russell L. And Ye Visited Me. New York: Harper and Brothers, Pub., 1939.

- Comfort Ye My People: A Manual of the Pastoral Ministry. New York: The Macmillan Company, 1947 .

- How to Make Pastoral Calls. St. Louis, Missouri: The Bethany Press, 1962.

1937. Meditations for the Sick. Chicago: Willett, Clark and Company,

- Pastoral Work and Personal Counseling. New York: The Macmilitan Company, 1945.

- Thy Health Sha11 Spring Forth. New York: The Macmillan Company, 1946.

- When You Call on the Sick. New York: Harper and Brothers, Fub., 1938.

Dobbins, Gaines S. A Ministering Church. Nashville: Broadman Press, 1960.

Dolloff, Eugene Dinsmore. A Crowded Church through Modern Methods. New York: Fleming H. Revell Company, 1946.

1959. The Pastor's Public Relations. Philadelphia: The Judson Press,

- The Romance of Doorbells. Philadelphia: The Judson Press, 1951.

Douglas, Lloyd C. The Minister's Everyday Life. New York: Charles Scribner's Sons, 1925.

Erdman, Charles R. The Work of the Pastor. Philadelphia: The Westminster Press, 1928.

Gladden, Washington. The Christian Pastor and the Working Church. New York: Charles Scribner's Sons, 1910.

Harmon, Nolan B. Ministerial Ethics and Etiquette. New York: Abingdon-Cokesbury Press, 1928.

Hiscox, Edward T. The Star Book for Ministers. Valley Forge: The Judson Press, $1 \overline{906 .}$

Hymnal of the Church of God. Anderson. Indiana: The Gospel Trumpet Company. 1953 . 
Jackson, Edgar N. The Pastor and His People: A Psychology for Parish Work. Manhasset, New York: Channel Press, Inc., 1963.

Jowett, J. H. The Preacher His Life and Work. New York: George H. Doran Cormpany, 1912.

Kandle, George C. and Henry H. Cassler. Ministering to Prisoners and Their Families. Paperback Edition. Philadelphia: Fortress Press, 1969.

Kent, Homer A. Sr. The Pastor and His Work. Chicago: Moody Press, 1963.

Lauterbach, William A. Ministering to the Sick. St. Louis, Missouri: Concordia Publishing House, 1955.

Lawson, James Gilchrist (comp.). The Best Loved Religious Poems. Westwood, New Jersey: Fleming H. Revell Company, 1933.

Lytle, Clyde Franeis (ed.). Leaves of Gold. Williamsport, Pennsylvania: The Coslett Publishing Company, 1938.

McAfee, Cleland Boyd. Ministerial Practices. New York: Harper and Brothers Publishers, 1928.

MoNeill, John T. A History of the Cure of Souls. New York: Harper and Brothers Publishers, 1951.

Perry, Lloyd Merle and Edward John Lias. A Manual of Pastoral Problems and Procedures. Grand Rapids: Baker Book House, 1964.

Pleune, Peter H. Some to Be Pastors. New York: Abingdon-Cokesbury Press, 1943.

Purkiser, W. T. The New Testament Image of the Ministry. Kansas City, Missouri: Beacon Hill Press, 1969.

Rodenmayer, Robert $N$. We Have This Ministry. New York: Harper and Brothers Publishers, 1959.

Riley, W. B. Pastoral Problems. New York: Fleming H. Revell Company, 1926.

Sangster, W. E. The Approach to Preaching. Philadelphia: The Westminster Press, 1952.

Savage, Henry Edwin. Pastoral Visitation. New York: Longmans, Green and Co.. 1903.

Scherzer, Carl J. Ministering to the Dying. Paperback Edition. Philadelphia: Fortress Press, 1967. 
Scherzer, Carl J. Ministering to the Physically Sick. Paperback Edition. Philadelphia: Fortress Press, 1968.

Schuette, Walter E. The Minister's Personal Guide. New York: Harper and Brothers Publishers, 1953.

Spann, J. Richard (ed.). Pastoral Care. New York: Abingdon-Cokesbury Press, 1951.

Thiessen, John Caldwell. Pastoring the Smaller Church. Grand Rapids: Zondervan Publishing House, 1962 .

Thomas W. H. Griffith. Ministerial Life and Work. Chicago: The Bible Institute Colportage Assn., 1927.

Wynn, John Charles. Pastoral Ministry to Families. Philadelphia: The Westminster Press, 1957.

Young, Richard K. The Pastor's Hospital Ministry. Nashville: Broadman Press, 1954.

\section{B. PERTODICAIS}

Ballinger, Malcolm B. "Pastoral Care of Sick and Injured Children," Pastoral Psychology, XIII (March, 1962), pp. 48-50.

Bonnell, George C. "The Pastor's Role in Counseling the Bereaved," Pastoral Psychology, XXII (February, 1971), pp. 27-36.

Brevis, Harry J. "Counseling Prison Inmates," Pastoral Psychology, VII (February, 1956), pp. 35-42.

Davidson, J. A. "Is Pastoral Calling Obsolete?" Pastoral Psychology, XV (March, 1964), pp. 43-46.

Grey, Alfred D. "The Pastoral Ministry," Pestoral Psychology, XIV (February, 1963), pp. 21-25.

Horne, Chevis F. "The Minister's Resources in the Sick Room," Pastoral Psychology, XXII (April, 1971), pp. 51-55.

Hubacek, Richard. "Hospital Visitation," Vital Christianity, XC (September 6, 1970), pp. 3-4.

- "When Death Comes," Vital Christianity, XCII (January 23, 1972), pp. 5-6. 
Hughes, Richard T. "Spiritual Crises Facing Surgical Patients," Pastoral Psychology, XXII (December, 1971), pp. 27-39.

Jackson, Edgar N. "A New Look at Pastoral Calling," Pastoral Psychology, XII (April, 1961), pp. 17-22.

Kennedy, James W. "The Doorbell Ministry." Pulpit Digest, XIVI (September, 1965), pp. 12-16.

Kuhnle, Howard A. "Pastoral Calling," Christianity Today, IX (June 4, 1965), p. 11 .

Mavis. W. Curry. "Must We Surrender Regular Pastoral Calling?" Pastoral Psychology. XIV (April, 1963), pp. 49-52.

Reed, Willis A. "The Pastor and Sick Visitation," Christianity Today, VI (June 8, 1962), pp. 6-7.

Rogers, William F. "The Pastor's Work with Grief," Pastoral Psychology, XIV (September, 1963), pp. 19-26.

Sparks, David E. "The Pastor and Hospital Visitation," The Nazarene Preacher, XIII (October, 1967), pp. 11-14.

Stanger, Frank Bateman. "How to Visit the Sick," The Herald, IXXXII (August 11, 1971), p. 16.

Wheeler, Paul. "Effective Pastoral Calling," The Wesleyan Methodist, CXX (September 1, 1965), p. 3. 